\title{
The Environmental Impact of Poverty: Evidence from Firewood Collection in Rural Nepal
}

\author{
Jean-Marie Baland ${ }^{1}$, Pranab Bardhan ${ }^{2}$, Sanghamitra Das ${ }^{3}$, Dilip Mookherjee ${ }^{4}$ and Rinki \\ Sarkar 5
}

July 312003

\begin{abstract}
We examine linkages between alternative measures of poverty and collection of forest firewood by rural households in Nepal in the World Bank 1995-96 Living Standards Measurement Survey. We find no evidence that increases in consumption were associated with a reduction in firewood collection, irrespective of whether we control for household size, education, occupation or productive assets owned. Increased consumption was associated with a positive, concave wealth effect, with no significant effect on shadow cost of time in collecting firewood. However, controlling for consumption levels, collections were significantly lower for households of smaller size, more primary schooling, more nonfarm employment and business assets. The results suggest that the effect of growth in living standards on firewood collection could be mitigated if accompanied by spread of primary education, growth of nonfarm occupations and drop in fertility.
\end{abstract}

\footnotetext{
${ }^{1}$ University of Namur

${ }^{2}$ University of California, Berkeley

${ }^{3}$ Indian Statistical Institute

${ }^{4}$ Boston University

${ }^{5}$ Indian Statistical Institute
} 


\section{Introduction}

The connection between poverty and environmental degradation is a central issue in development economics. Environmental policy discussions in less developed countries are dominated by the poverty-environment hypothesis ( $\mathrm{PEH}$ ) which asserts that poverty forces households to rely on environmental common property resources (ECPRs) for their survival. ${ }^{6}$ According to the $\mathrm{PEH}$, halting environmental degradation requires as a prior step the reduction of poverty, via growth or redistributive public policies. A related literature on environmental Kuznets curves (EKC) examines the connection between per capita income and environmental degradation, mainly on the basis of cross-country macro evidence. ${ }^{7}$ The EKC literature points to an inverted-U between economic development and environmental degradation. It differs from the $\mathrm{PEH}$ in asserting that development at early stages may increase strain in ECPRs. However beyond some threshold level, both hypotheses predict that further development will slow the rate of environmental damage.

Neither hypothesis has been subjected to detailed micro-econometric investigation, with a few recent exceptions. ${ }^{8}$ This paper examines the link between living standards and collection of forest firewood on the basis of household level evidence in rural Nepal from the 1995-96 Living Standards Measurement Survey (LSMS). We distinguish between different formulations of these hypotheses employing different definitions of poverty or living standards, and the set of household or village characteristics controlled for. The most commonly employed definition of living standards is in terms of consumption levels, though alternative definitions of poverty rely on absence of suitable assets or education. In examining poverty environment linkages, therefore, we can distinguish between consumption-based and assetbased versions (and refer to them as the CPEH and APEH respectively). Moreover, we can distinguish between conditional or unconditional versions of each of these hypotheses.

\footnotetext{
${ }^{6}$ Initially proposed by the 1987 Brundtland Commission and the Asian Development Bank (Jalal (1993)), it has subsequently received attention from academics and policy experts (Barbier (1997a, 1998, 1999), Duraiappah (1998), Jalal (1993), Lele (1991), Lopez (1998), Maler (1998)).

${ }^{7}$ For instance, see Barbier (1997b), Grossman and Krueger (1995), Yandle, Vijayaraghavan and Bhattarai (2002).

${ }^{8}$ These include Chaudhuri and Pfaff (2002) and Foster and Rosenzweig (2002).
} 
The conditional version of the $\mathrm{CPEH}$ asserts that a rise in consumption of a household beyond the poverty line would lower its reliance on ECPRs, holding fixed relevant household characteristics (such as education, asset composition, occupation and demographics). The corresponding conditional version of the APEH defines household poverty directly in terms of these household characteristics (e.g., lack of education, land or nonfarm assets, reliance on traditional livestock based occupations, large household size) and examines their connection with ECPR reliance, holding consumption fixed. These correspond to different definitions of the development process: the CPEH pertains to growth in consumption levels per se, while the APEH focuses on the effects of spread of education, access to modern occupations and reduction in household size.

Of course it is often the case that growth in consumption standards goes hand in hand with the spread of literacy, modern occupations and falling fertility. So focusing exclusively on either (conditional) versions of the APEH and CPEH may miss the effects of such interactions. Accordingly one can examine their respective unconditional versions. The unconditional version of the $\mathrm{CPEH}$ would assert that rising consumption standards of the poor would reduce their reliance on ECPRs, without controlling for household characteristics such as education, occupation and size. The indirect effects of rising consumption that occur from induced changes in education, occupations or fertility would be incorporated in the unconditional version. Conversely, the unconditional version of APEH incorporates wealth as well as cost of collection effects of increased asset ownership, so does not control for consumption levels. In this paper we will examine the evidence in favor of both conditional and unconditional variants.

Section 2 of the paper provides the theoretical underpinning of our specification of the firewood Engel curves. Section 3 describes the data. Section 4 presents simple OLS Engel regressions at both cross-village and intravillage levels. It then discusses a number of econometric problems (omitted variables, endogeneity and censoring biases) these regressions are potentially subject to. These problems are confronted in Section 5, which presents our principal results on the conditional Engel curves based on variations across households within villages. Section 6 thereafter seeks corroboration of the intravillage Engel relationships at the inter-village level, though the results at this level are less reliable. Section 7 then exam- 
ines evidence in favor of corresponding unconditional versions of $\mathrm{CPEH}$ and APEH. Section 8 presents some simulations of the model with respect to rises in consumption standards, demographic pressure, spread of literacy and modern nonfarm occupations. Section 9 discusses related literature, while Section 10 concludes with a discussion of shortcomings of our analysis and of future research directions. Details of the underlying theory and econometric methodology are presented in Appendices A-C.

Our principal findings are the following. We find no evidence supporting either conditional or unconditional variants of the $\mathrm{CPEH}$. The relationship between consumption and firewood collection appears for most part to be increasing and concave. Only in some regressions does an EKC type pattern emerge, with rises in consumption at the very top end of the distribution associated with a drop in firewood collection.

We decompose the (conditional) Engel effect into a wealth effect and a cost of collection effect. The wealth effect tends to be positive and dominant of the two: the households in our sample manifest no switch to alternative fuels with rising consumption levels. The cost of collection which consists mainly of the time taken to collect firewood from the forest (valued at the shadow cost of the household's time) shows no significant variation with consumption standards.

We do however find evidence in favor of the conditional version of the APEH. Holding consumption levels fixed, higher levels of literacy, nonfarm employment, nonfarm business assets, and lower household size were associated with significantly lower firewood collections (via their effect on the shadow cost of collection time). If consumption is not controlled for, as in the unconditional version of the APEH, increased asset ownership incorporates wealth as well as cost of collection effects. Here we find that firewood collection decreases significantly only with respect to ownership of nonfarm business assets (and that too only in the low-lying terai region which is more urbanized). For all other assets the wealth effects are positive, concave and frequently insignificant. Overall, thus, there is no evidence in favor of the hypothesis of significantly negative wealth effects associated with rising living standards, irrespective of how the latter happen to be defined. On the other hand, 'modernization' defined as increasing education, nonfarm occupations and falling fertility 
do exercise a strong moderating effect on firewood collection, by raising the shadow cost of collection time.

This suggests that the effect of economic development depends primarily on the extent to which growth in living standards is accompanied by modernization. Simulations of the estimated relationships suggest an almost unitary elasticity of firewood collected with respect to consumption levels and population pressure, but the effect of $40 \%$ rise in consumption could be neutralized by universal primary education in rural Nepal.

\section{Theory}

Household $i$ in village $v$ has a utility function

$$
U_{i v}=u\left(F_{i v}, q_{i v}, l_{i v}, s_{i v}\right)-\xi\left(F_{i v}-\frac{F_{v}}{n_{v}}\right)
$$

where $F_{i v}$ denotes firewood used by the household, $q_{i v}$ denotes quantity of other goods consumed, $l_{i v}$ denotes leisure time (including time devoted to household tasks), $s_{i v}$ denotes family size and composition. $\xi$ denotes the effect of village norms, an increasing and convex function of deviation of household consumption from the village average $\frac{F_{v}}{n_{v}}$, where $F_{v} \equiv$ $\sum_{i} F_{i v}$ is aggregate firewood used in the village, and $n_{v}$ is the number of households in the village. The latter represents a pure 'peer' effect in consumption, or the present value of utility deviations in future periods resulting from sanctions imposed by the rest of the village for excessive current consumption.

Each household takes as given village prices of all other goods (denoted $p_{v}$ ), and firewood consumption of the rest of the village. Then given a level of expenditure $E_{i v}$ net of pecuniary costs of firewood, household size and composition $s_{i v}$, the household has the following indirect utility function

$$
W_{i v}=w\left(F_{i v}, l_{i v} ; p_{v}, E_{i v}, s_{i v}\right)-\xi\left(F_{i v}-\frac{F_{v}}{n_{v}}\right)
$$

where $w($.$) is obtained by maximizing u($.$) subject to p_{v} . q_{i v} \leq E_{i v}$. We assume that this indirect utility function is strictly concave with respect to $F_{i v}$. 
Owing to data limitations we will ignore the possibility of firewood markets within the village. About one-tenths of the Nepal LSMS sample households purchase some firewood: the smallness of this sample makes it difficult to study purchase-sale decisions with any accuracy. We therefore assume that firewood used must be entirely collected by the household itself.

The cost of using firewood includes two components: (i) the time it takes to collect, valued at the shadow cost of this time to the household, and (ii) any fees that the household may have to pay to a forest guard. The shadow cost of time depends on the household's assets, employment opportunities, and allocation of its labor across different occupations and tasks. We explain below how these are determined.

The time $T_{i v}$ taken to collect one unit of firewood by household $i$ in village $v$ depends (besides the household's own location within the village) on the proximity and density of the forest stock. In turn the latter depends on the historical forest endowment $F S_{v}$ of the village, and on extraction activities of village residents besides other factors collectively captured by $\mathrm{T}$ :

$$
T_{i v}=T+\delta\left(F S_{v}-F_{v}\right)+\epsilon_{i v}
$$

Here $F S_{v}$ denotes the historical forest stock endowment of the village, and $\epsilon_{i v}$ an idiosyncratic mean-zero household deviation from the village average time which depends on the exact location of the household. Equation (3) incorporates an extraction externality across households: greater extraction by others causes the forest stock to dwindle, increasing the time required to extract by any given household.

Let $c_{i v}^{l}$ denote the opportunity cost of a household's time. Then (assuming an interior solution) the household's best response to the collection activities of others in the village can be shown (as elaborated in Appendix A):

$$
F_{i v}=\beta_{1}+\beta_{21} E_{i v}+\beta_{22} E_{i v}{ }^{2}+\beta_{3} s_{i v}+\beta_{4} \frac{F_{v}}{n_{v}}+\beta_{5} c_{i v}^{l} T_{i v}+\beta_{v}+e_{i v}^{1}
$$

where $e_{i v}^{1}$ is a zero-mean error. The pure wealth effect is represented by consumption and its square, and the cost of collection effect by the interaction between collection time and the shadow cost of the household's time. The coefficient $\beta_{4}$ represents the effect of village norms, while $\beta_{v}$ is a village fixed effect. 
The shadow cost of time is endogenously determined by how the household allocates its time. As explained in more detail in Appendix A, the shadow cost depends on household consumption (if there are wealth effects on the demand for leisure), the time devoted to collection $\left(T_{i v}\right)$, besides household characteristics such as household size $\left(s_{i v}\right)$, assets owned $\left(\theta_{i v}\right)$, and village parameters such as wages and prices. For instance households owning much livestock are likely to spend more time grazing the livestock, an activity complementary with collecting firewood. Those employed in nonfarm occupations in contrast are likely to employed in neighboring markets or town areas, for whom it is difficult to find the time to collect firewood from the forest. Incorporating these determinants of shadow cost, and the possibility of corner solutions for collection levels ${ }^{9}$, we obtain the following best response equation:

$$
\begin{aligned}
F_{i v}= & \max \left[0, \beta_{0}+\beta_{21} E_{i v}+\beta_{22} E_{i v}^{2}+\beta_{3} s_{i v}+\beta_{5} T_{i v}+\beta_{6} T_{i v}^{2}+\right. \\
& \left.+\beta_{7} E_{i v} T_{i v}+\beta_{8} \theta_{i v} T_{i v}+\beta_{9} s_{i v} T_{i v}+\beta_{v}+e_{i v}^{4}\right]
\end{aligned}
$$

where $\beta_{v}$ is a village fixed effect which includes the average collection in the village and other village parameters affecting the shadow cost of household's time. ${ }^{10}$

The conditional Engel curve represented by (5) relates intravillage variations in consumption levels and household characteristics with firewood collection. Consumption levels are in turn determined by household characteristics:

$$
E_{i v}=\nu_{1}+\nu_{2} \theta_{i v}+\nu_{3} s_{i v}+\nu_{4} I_{i v}+\nu_{v}+\eta_{i v}^{2}
$$

where $I_{i v}$ denotes a set of instruments for consumption, $\nu_{v}$ a village fixed effect, and the error term includes effect of transitory shocks and omitted characteristics. Asset ownership and household size thus affect collections in two ways: via their impact on consumption, and via their impact on cost of collection time. Accordingly we can interpret the terms involving consumption in (5) as the pure wealth effect on collections, the interaction term

\footnotetext{
${ }^{9}$ Here we exploit the fact that indirect utility of the household is concave with respect to firewood, while the marginal cost is increasing.

${ }^{10}$ In the estimation we however dropped the interaction between household size and collection time because these turned out to be insignificant in all versions we estimated.
} 
$E_{i v} T_{i v}$ with wealth effects on the shadow cost of time, and the interaction term $\theta_{i v} T_{i v}$ as the effect of asset ownership on the shadow cost of time. The conditional version of the CPEH corresponds to the hypothesis that holding assets and household size fixed, a rise in consumption lowers collections via two possible channels: (a) negative wealth effects $\left(\beta_{21}, \beta_{22}<0\right)$, and (b) higher shadow cost of time $\left(\beta_{7}<0\right)$. The conditional version of the APEH asserts that holding consumption fixed, increases in asset ownership (e.g., of human capital, nonfarm assets) or falling household size lower collections by raising the shadow cost of time $\left(\beta_{3}>0, \beta_{8}<0, \beta_{9}>0\right)$.

\section{Description of Data}

\subsection{Descriptive Statistics}

Tables 1 and 2 provide descriptive statistics concerning household and village characteristics respectively. The World Bank Living Standards Measurement Survey (LSMS)for Nepal covers 274 wards, of which 215 are rural. We use only the data for the rural wards, involving 2712 households, who were interviewed concerning their production and consumption activities for the year 1995-96. Nearly one third of the sample did not collect firewood at all. On average a household collected 5.8 bharis or bundles of firewood a month. For those who collected per bhari collection time was over five hours on average, with significant variation across households (a coefficient of variation approximately one). The average elevation above sea level was around 3100 feet, with a standard deviation of 3100 feet, implying considerable variation in elevation, going up to a maximum of 17,000 feet. Many of these villages were spread out, resulting in an average within-village standard deviation of collection time of 1.8 hours. Households mentioned adults as the principal collectors of firewood, and females somewhat more important than males in this respect (average number of adults collecting per household was 1.56, of which female adults accounted for 0.94). $77 \%$ of the households collected firewood from a government or community forest, with the remaining households collecting either from their own lands or other sources (such as from roadsides). 
The mean annual consumption for a household was Rs. 35,000. Given the average household size was 4.4 (in adult equivalent units), corresponding to annual per capita consumption of approximately $\$ 250$ (in 1995-96 prices). The average poverty gap (relative to a poverty line of $\$ 1$ per day per capita) was $14 \%$, while that relative to $\$ 1.50$ per day was $43 \%$, indicating high levels of poverty. $13 \%$ of the households were headed by women. The majority were engaged in self-employed agricultural activities and livestock rearing. Principal assets consisted of cultivated land, livestock and nonfarm business assets. Education levels were low: $70 \%$ of heads of households had no education. In terms of religion, the households were predominantly Hindu: only $6 \%$ were Buddhists, $4 \%$ Muslim and $1 \%$ belonged to other religions. $35 \%$ belonged to upper castes (brahmin or chhetry), $28 \%$ to middle castes (magar, thuru, newar, tamang, rai, gurung, limbu), $13 \%$ to lower castes (kami, damai and surki). Hence there was greater ethnic than religious fragmentation. $11 \%$ of the households reported migrating into the village for non-economic reasons within the current and previous generation.

The villages were fairly remote from modern transport and communication: the average distance to dirt roads, markets or agricultural extension services took more than 3 hours to traverse (frequently on foot), with paved roads 8 hours away. They were also fairly disaster prone, with $56 \%$ of the villages having experienced a natural disaster within the previous five years.

Table 3 shows that wood fuel was the main source of energy for cooking and heating for $74 \%$ of the households (the other leading sources being cowdung (18\%) and leaves or straw $(6 \%))$. Only $3 \%$ of the households used kerosene or gas as the primary source of cooking or heating fuel, and a comparably miniscule proportion used kerosene/gas stoves. Hence modern fuel sources were conspicuous by their absence. However, kerosene was used by $83 \%$ households as the principal source of lighting, so there was wide access to kerosene. The low use of kerosene or gas may owe to limited availability or high cost of kerosene/gas, of kerosene/gas stoves, or persistence of traditional cooking and heating practices.

The villages varied considerably with regard to elevation, which ranges from 190 to 17000 feet above sea level. The low lying terai region, usually defined by an elevation of up 
to $1000 \mathrm{ft}$ above sea level, has experienced the greatest deforestation since the 1950s. This is frequently attributed to demographic pressure arising from successful malaria control, development of nonfarm opportunities and rapid in-migration from higher non-terai villages (Metz (1991)). Table 4 shows the principal characteristics of these two regions in the LSMS sample. Approximately $60 \%$ of the households in the sample are from the non-terai region. The two regions do not differ significantly with respect to average consumption, household size or education standards. However, two-thirds of terai households do not collect firewood at all (compared with $8 \%$ in the non-terai), and the remaining collect one-third of what non-terai households do. This is despite the fact that collection times are approximately the same in both regions. The two regions do differ significantly with regard to occupational structure: despite a higher value of farm land relative to nonfarm assets, a higher fraction of household employment in the terai is in the non-farm sector.

The government of Nepal introduced a community forestry scheme in 1993, handing over forest areas to be managed by local communities. ${ }^{11}$ In our sample, the average (across villages) of the fraction of households within a village who reported collecting from a community forest was $11 \%$, and $43 \%$ of the villages had at least one such household in the sample. Unfortunately the LSMS questionnaire did not include a direct question about membership. Consequently we do not include this information among the set of household characteristics owing to the possible measurement error it entails, besides the potential endogeneity of this variable. ${ }^{12}$ We do, however, include a village dummy variable where a

\footnotetext{
${ }^{11}$ The 1993 Forest Act defined 'forest user groups' as autonomous corporate bodies that were assigned control over designated forest areas 'in perpetuity'. The user groups draw up a five year plan to manage, protect and share forest produce. The use of forest products is subject to regulations and charges; the groups hire forest guards to monitor compliance. The groups also plan and implement reforestation schemes. Over 8000 user groups had been created by 1999, with the government handing over over 600,000 hectares to groups in 74 out of 75 districts. See Mahapatra (2000). The government plans eventually to hand over 3.5 million hectares to local communities in this way, representing $61 \%$ of all forest land in Nepal. Implementation of the scheme has been gradual, so many communities are yet to form forest user groups. Edmonds (2000) argues that exogenous factors such as proximity to towns and district capitals have determined the selection of communities where forest user groups have been created.

${ }^{12}$ Accounts of the creation of these groups (Mahapatra (2000)) indicate they followed investigations by the government of forest dependence on a household-by-household basis, which implies that membership could
} 
user group is defined to exist if at least one household reported collecting from a community forest. Hence only the intervillage regressions will permit estimation of the effect of user groups on collections.

\section{Simple Representations of the Consumption-Collections Relationship}

The raw data shows that for households who collect firewood, collections do not decrease with consumption of households within the same village. Figure 1 plots the $95 \%$ confidence band for mean deviation of firewood collection from the village mean for twenty different percentile groups (each corresponding to a five percentile group) against corresponding deviations in consumption levels of these different groups. It shows no support for the unconditional version of the CPEH: groups in the lowest percentile groups collect significantly less (with a difference of more than three bharis, which substantially exceeds the width of the $95 \%$ confidence band).

Figure 2 displays the corresponding intervillage consumption-collection relationship. It

plots mean village collection against mean consumption levels. Here the highest levels of collection are manifested by villages with the lowest and highest consumption levels, with no overall trend.

Table 5 presents results of simple OLS regressions at both intravillage and intervillage levels. The intravillage regressions use household collections as the dependent variable, and include village fixed effects. Both include upto two or fourth order terms in consumption, besides the interaction between consumption and collection time. The intervillage regression uses the village average of household collection as the dependent variable, and controls for the fraction of households in forest user groups, inequality in consumption and land, and some other village characteristics. Measures of education, occupational structure and demographics are excluded. So these are the unconditional Engel curves. The predicted be the effect of high levels of firewood collection. Since membership is a dummy variable it proved difficult to predict on the basis of household instruments. 
Engel relationships (the fourth order polynomial versions) are plotted in Figures 3 and 4 respectively. Both display a positive relationship between consumption and collections over most of the range of consumption, except at the very top where there is a tendency for the slope to flatten and turn negative. So there appears to be no evidence in favor of the unconditional version of the $\mathrm{CPEH}$ from either regression, with limited evidence of an EKC pattern at the top end. Note also the estimated interaction between consumption and collection time is positive and significant in the intravillage regression, contrary to the prediction of the $\mathrm{CPEH}$ that shadow cost of collection time is higher for households with higher living standards.

\section{Household-Level Intra-Village Estimation}

The OLS regressions reported in Table 5 are subject to a number of potential econometric problems. First is the problem of potential endogeneity of consumption levels. Unobserved variables (such as the size of the forest stock, climate, access to fuel substitutes) can jointly affect consumption levels as well as collection activities. Many of these arise at the level of the village, and so particularly afflict the intervillage regression. For this reason the intravillage regressions are more reliable, as the fixed effects control for unobserved village attributes. Nevertheless even the intravillage regression may be subject to endogeneity bias owing to omission of household characteristics (reflecting effort disutility, discount rates etc.) that affect both consumption and collections. The second problem arises from censoring, since between a third and quarter of the households do not collect at all. Moreover, collection times are unobserved for the noncollecting households. Dropping such households from the sample would create a potential bias in the estimates.

In this section we report results of the intravillage regressions with village fixed effects which correct for the censoring bias. The econometric procedure is explained in detail in Appendix B. At the first stage we estimate unobserved collection times for the non-collectors, based on estimates of the relationship between observed household characteristics and collection times for collectors. For this we use Kyriazidou's (1997) estimator for endogenous sample selection with panel data. Then at the second stage we estimate the censored re- 
gression (5) using the collection time predictions from the first stage. Here we use the semiparametric estimator proposed by Honore (1992) for censored data with fixed effects.

To allow for potential endogeneity of consumption at the household level, we also present results for a version where actual consumption is replaced by predicted consumption from a prior regression on the basis of a set of household characteristics and instruments. Instruments for consumption include ethnicity, age of head of household, value of land inherited by the head, education and occupation of parents of the head. The versions which use predicted consumption as a regressor can accordingly be interpreted as using a measure of permanent consumption as a determinant of collection levels. Since the standard errors reported by Honore's program (called PANTOB) assume all the regressors are exogenous, they understate the true standard errors for not allowing for prediction errors for permanent consumption (besides collection time for non-collectors). Accordingly in order to obtain the true standard errors we bootstrap the resulting coefficient estimates; these turned out to be very close to the standard errors reported by PANTOB.

Table 6 presents estimated coefficients of the panel household regressions with censoring. Regression 6.1 excludes interaction between consumption and collection time, while 6.2 shows the effects of including this interaction. Regression 6.3 corresponds to the case where consumption is treated as exogenous, and 6.4 where it is endogenous but the square of consumption is dropped. Implied elasticities and effects of one standard deviation changes in each variable on latent collections are shown for regression 6.1 in Table 7.

Firewood collection is increasing and concave in consumption when it is treated as endogenous, though these coefficients are not statistically significant. The hypothesis of zero or positive wealth effects cannot be rejected: hence the evidence does not favor the the conditional version of the PEH. Measurement error in permanent consumption is likely to bias the estimated coefficient downward, which reinforces this conclusion.

The estimated elasticity of collections with respect to consumption exceeds one at the bottom of the distribution, but becomes less than one at the median and above. Hence the reliance on firewood collections expressed as a proportion of consumption rises at the bottom end of the distribution, and falls thereafter. The latter is consistent with the 
numerous studies in Asia and Africa documenting that the ratio of CPR use to consumption is highest among the poor (e.g., Beck and Nesmith (2001)). In this sense it is true that the poor depend more than the nonpoor on firewood. Yet this does not imply that a reduction in poverty would reduce pressure on the forests, since a rise in consumption of the poor would raise their collections in absolute terms. The relevant criterion is whether the elasticity is positive, not whether it is less than one. The latter fact is pertinent instead to the distributional impact of deforestation: a less than unit elastic demand for firewood implies that the (proportional) impact of deforestation on the living standards of the poor would be greater than for the nonpoor.

Table 6 separates the effect of rising consumption into the wealth and cost-of-collection effects. The wealth effect is rising and concave in the versions where consumption is treated as endogenous, and rising and convex if actual values of consumption are used. Only in the latter case is the effect statistically significant at $10 \%$. Hence irrespective of how consumption is measured, there is no evidence in favor of the hypothesis of negative wealth effects. Presumably the cause lies in the restricted use of modern fuel substitutes that was shown in Table 3, owing to restricted access or high cost of these substitutes. As a household's living standards rise, its energy needs rise; in the absence of reasonably priced fuel substitutes they are forced to rely on higher collections of firewood from the forest. The absence of reliable data in the LSMS on access to or cost of alternative fuels however prevents us from exploring the reasons for the absence of switch to alternate fuels that has been observed in some countries as living standards rise.

The other source of evidence against the conditional version of the $\mathrm{CPEH}$ concerns its predictions concerning the shadow cost of collection time. The interaction of consumption with collection time is positive and insignificant. So there is no evidence that higher wealth per se raises the shadow cost of collection time. We explore possible reasons for this result later in this section.

On the other hand, there is evidence in favor of conditional versions of the APEH. Collections significantly increase in household size, with a coefficient slightly less than unity. Since the regression already controls for consumption, this suggests the role of increasing 
stock of household labor available for collecting firewood, and increased fuel need (e.g., for heating, which is presumably not reflected in measured consumption). Apart from consumption and household size, the significant determinants of firewood collection are interactions with collection time of land, nonfarm assets owned, and education of head of household. These are negative and significant. Since the regression controls for the wealth effect of asset ownership via consumption, these interactions can be interpreted as effects of occupational structure on the shadow cost of collection time. The signs of the estimated interactions are consistent with this interpretation: higher farm or nonfarm assets and hence lower livestock ownership shifts households away from livestock grazing and firewood collection activities. Household age and gender composition have the signs expected, but are insignificant. Owing to locational dispersion of the households within villages, we also included proximity to the nearest market area and to the nearest shop (which may affect access to fuel substitutes), but these turned out to be insignificant.

The effect of occupational structure on collections is further explored in Table 8, the first column of which replaces the interactions of collection time with different assets by its interaction solely with the fraction of household working hours in nonfarm occupations. This is negative and significant. Hence a greater reliance on nonfarm occupations significantly lowers shadow cost of collection time, presumably since such occupations require household members to work in neighboring urban or semi-urban locations located further away from the forest. The second column of Table 8 examines the determinants of reliance on nonfarm occupations. Households whose heads are more educated, male, and whose parents were also employed in nonfarm occupations tend to be more involved in nonfarm occupations.

To check that the foregoing results are not affected by aggregation of terai and non-terai households, we re-estimated regression 6.1 in Table 6 for each group separately. Due to missing values, the regression sample for terai reduced to only 343 observations while that for non-terai reduced to 1084 observations. As seen in Table 4 censoring is much higher in the former. The results are reported in Table 9. Education turns out to be important in both regions. But the effect of occupational choice on collection differs according to whether land or business assets are more important (see Table 4). The other main difference between the regions is that collections in the terai do not vary with household size, and the terai exhibits 
a significant location effect. Similar to the pooled data, the estimated relationship with consumption is increasing and concave within both regions and statistically insignificant. In other words there is no evidence in any region in favor of the conditional version of PEH. The same is true in the raw data as shown in Figure 5 and Figure 6. Hence our principal conclusions are unaffected when the firewood collection equation is estimated separately for the terai and non-terai.

To understand further the reasons for the lack of relation between shadow cost of collection time and consumption, we next examine the allocation of collection responsibility within households. Underlying the $\mathrm{PEH}$ is the idea that wealthier households principally have higher productive assets, implying a higher return on the time of these households allocated to the corresponding productive activities. However, this implies a higher shadow cost of collection time only under the additional assumptions that (i) devoting more time to productive activities cuts into time available for household tasks or leisure, and (ii) the marginal utility of the latter is diminishing over this range. If the household stock of labor is large enough relative to time devoted to productive activities, there can be enough 'slack' within the household that time devoted to productive activities does not cut into time available for household tasks. This may be so in a traditional rural society where children and extended family members live nearby can be called upon to help out with firewood collection and other household tasks.

The Nepal LSMS contains information about the collectors of firewood within the household. Table 10 presents this information for households classified into different per capita consumption quartiles. For each quartile it presents the per household reliance on different types of household members. Households in higher consumption quartiles rely less on the household head and more on the spouse of the head. A clearer picture of patterns of intrahousehold substitution of tasks among members is shown in Table 11, which partitions the sample into households of differing size (measured in adult equivalent units), and within each size class presents the same information across different quartiles of total (rather than per capita) consumption. As household size increases, there is a stronger tendency for wealthier households to switch reliance away from the household head towards children and others (primarily servants and extended family members). 


\section{$6 \quad$ InterVillage Regressions}

In this Section, we explore the effect of village characteristics on household collection incentives. This involves estimation of determinants of the village fixed effects in the household collection equation. As explained earlier, the problem of unobserved heterogeneity is substantially more severe at the level of the village, so intervillage analysis is inherently prone to more biases than the intravillage regressions. Nevertheless it is interesting to examine whether intervillage patterns are consistent with those identified at the intravillage level.

One component of village effects stem from conformity norms wherein each household's collection responds to the collection of others in the same village. Equation (4) represents the best response of a household (ignoring censoring issues). Letting $\omega_{i v}$ denote the set of household characteristics that appear in this equation, and $\boldsymbol{\beta}$ the corresponding coefficient vector, we can represent this response equation more compactly as follows:

$$
F_{i v}=\left[\beta_{0}+\boldsymbol{\beta} \cdot \omega_{i v}+W_{v}\right]+\beta_{4} \frac{F_{v}}{n_{v}}+e_{i v}^{4} .
$$

It is natural to expect that increases in the collection of others induces each household to collect more, i.e., $\beta_{4}$ is positive. This is inherent in the nature of peer effects and social sanctions that create pressures for conformity. Under the additional 'stability' condition that $\beta_{4}$ is less than one, we can solve for the equilibrium collections in the village as a function of village average $\boldsymbol{\omega}_{v}$ of the relevant household characteristics:

$$
\frac{F_{v}}{n_{v}}=\frac{1}{1-\beta_{4}}\left[\beta_{0}+\boldsymbol{\beta} \cdot \boldsymbol{\omega}_{v}+W_{v}\right]
$$

The response of village average collections with respect to the average of any relevant household characteristic will be a multiple of the corresponding coefficient in the household response equation. This is a consequence of the 'multiplier' effect induced by the social norms: a small change in a characteristic of one household that causes this household to collect more, induces other neighboring households to also collect more, which reflects back on the original household, creating a sequence of exponentially declining 'ripple' effects.

This multiplier property suggests a way of using a cross-village regression (8) to independently confirm results obtained from the intra-village household regression. For instance 
if collections are increasing (resp. decreasing) with respect to some characteristic at the household level, the same should be true for cross-village variations of corresponding village averages.

However, the village effect $W_{v}$ may also depend on village characteristics $\boldsymbol{\omega}_{v}$. For instance, recall that the collection charge $c_{v}^{f}$ enters the village effect $W_{v}$, and reflects the nature of forest management, and thus ultimately on the nature of collective action within the village community. Theories of collective action suggest the importance of population size, average living standards, preference heterogeneity concerning collective goods, social fragmentation and remoteness of the community from the outside world as important determinants. ${ }^{13}$ Hence there will be substantial overlap between averages of household-level determinants, and determinants of the extent of collective action. Other community-level determinants of household marginal utility and cost of firewood collection (which enter $W_{v}$ ) may include geography and remoteness, which may be correlated with consumption standards and forest proximity.

We therefore postulate that the determinants of the village effect $W_{v}$ include elements of $\boldsymbol{\omega}_{v}$ such as average levels and inequality in consumption, and a variety of village level variables (represented by the vector $\phi_{v}$ ) that potentially affect collective action and geography:

$$
W_{v}=\sigma_{0}+\boldsymbol{\sigma}_{1} \cdot \boldsymbol{\omega}_{v}+\boldsymbol{\sigma}_{2} \cdot \boldsymbol{\phi}_{v}+\varepsilon_{v}
$$

The vector $\phi_{v}$ includes population size, poverty, landownership inequality, locational heterogeneity (reflecting preference heterogeneity and extent of mutual monitoring), ethnic fragmentation, forest user groups, besides geographical determinants of dependence on firewood (such as altitude and remoteness from roads and markets).

To correct for censoring bias, we estimate the coefficients of (9) from a random effects tobit applied to residuals from the intravillage regression estimated previously. Mean consumption and collection times are instrumented using averages of household instruments for these used in the intravillage regression. Further details of the estimation procedure are

\footnotetext{
${ }^{13}$ For instance, see the Symposium on Management of Local Commons in the Journal of Economic Perspectives, 1993.
} 
provided in Appendix C.

Table 12 presents estimates from this regression. Included as potential determinants of collective action within the village are population size, inequality in consumption and in landownership, proximity of the forest (representing the stakes of the community in forest conservation), average gap below the poverty line of 1 a day per capita, ethnic fragmentation $^{14}$, standard deviation of collection times and fraction of households belonging to forest user groups. Geographical determinants of need and collection cost include elevation, a dummy for occurrence of natural disaster in the previous five years, and proximity to roads and market centers. Apart from this we include averages of all variables entering the household regression, unless they have already been included within the list of collective action determinants.

The results of Table 12 are consistent with the previous household results, in conjunction with standard theories of collective action. Among the variables entering exclusively via their impact on collective action, only ethnic fragmentation has a significant (positive) impact. This variable captures difficulties that ethnically divided communities encounter in evolving and implementing common codes of conduct. Moreover social sanctions may be limited to members of one's own caste, which implies weaker average levels of social sanctions in more heterogenous villages. The only other collective action determinant of moderate significance is dispersion of collection times (which captures the extent of mutual monitoring and preference diversity within the village). Inequality, poverty and population size in particular do not have any significant effect. The effect of the forest user groups on collection activities appears to be insignificant.

Regarding average consumption, the effect is positive and significant, reinforcing our earlier evidence against the conditional version of $\mathrm{CPEH}$ in the intravillage analysis. The higher significance of consumption at the village level could either reflect the multiplier effect resulting from social norms, or weaker collective action in more well-off villages. It is encouraging to note that the coefficients of asset ownership patterns (interacted with

\footnotetext{
${ }^{14}$ The measure of ethnic fragmentation is the probability that any two randomly chosen households in the sample belong to the same caste group (upper, middle or lower).
} 
collection time) have exactly the same patterns of signs as in the intravillage regression, but larger magnitude. The estimated coefficients here are two to five times larger. The coefficients are however imprecisely estimated, with only the education variable statistically significant. Consequently we find that the results concerning village level determinants are consistent with those identified in the previous Section.

\section{Testing the Unconditional Versions of CPEH and APEH}

The preceding sections have considered the effects of consumption while controlling for education, asset ownership and household size, and argued that the evidence does not provide support for the conditional version of CPEH. We now present the corresponding unconditional versions of the intravillage and intervillage Engel regressions, which incorporate indirect effects of consumption on collections via their induced impact on education, asset ownership and fertility. Earlier in Section 4 we presented OLS versions of these regressions, but these were subject to potential censoring and endogeneity biases. Table 13 shows the estimates of the unconditional Engel regressions which incorporate the censoring in the data, using exactly the same estimators used in the previous two sections. The first column shows the estimates of the intravillage regression when household consumption is instrumented. The next two columns show the corresponding estimates when consumption is treated as exogenous, with a quadratic and fourth order polynomial specification respectively. The last column shows the results of the random effects tobit at the intervillage level. Figure 7 plots the resulting predicted relationship between collections and consumption. The pattern of the unconditional predictions is similar to those of the conditional predictions: collections are rising and concave in consumption. Moreover, there is no evidence of a higher cost of collection effect for wealthier households.

Table 14 shows the corresponding estimates of the unconditional version of APEH at the intravillage level after correcting for censoring bias. Consumption is replaced by ownership of farm land, nonfarm business assets, cows owned, and education of household head. The first column shows the results when we include the squares of each asset owned along with the linear terms, while the second drops the squares. Only nonfarm assets owned has a 
significant negative effect on collections. The third column interacts nonfarm assets with a dummy for the nonterai. It is apparent that the significant negative effect is confined only to the terai. This is confirmed in the fourth column, which runs the regression only for the nonterai sample - here nonfarm assets cease to have a significant effect. ${ }^{15}$ Therefore a drop in poverty significantly reduces collections only when that happens to result from increased ownership on nonfarm business assets, and that too only for households that reside in the terai. In general asset increases of other kinds do not have a significant moderating effect on collections: they tend to have a positive concave effect instead. We therefore suspect that the negative effect of nonfarm assets in the terai proxies for exposure to fuel substitutes, and less resistance to modern cooking and heating methods, rather than a decline in poverty per se.

\section{Simulations}

Finally, Table 15 combines the results of the inter-household and village effect regressions to simulate the effects of changes in some of the significant determinants of village-wide collection levels. Specifically, we simulate changes in collection activities at the household level from the combined model

$$
F_{i v}=\max \left[0,\left(\beta_{0}+\psi_{0}\right)+\boldsymbol{\beta} \cdot \omega_{i v}+\boldsymbol{\psi}_{1} \cdot \boldsymbol{\omega}_{v}+\boldsymbol{\psi}_{2} \cdot \boldsymbol{\phi}_{v}+\xi_{v}+e_{i v}^{4}\right]
$$

where $\boldsymbol{\beta}$ is estimated from the inter-household regression reported (for Version 6.1) in Table 6 , and $\boldsymbol{\psi}_{i}, i=1,2$ from the village effect regression reported in Table 11. Effects of asset changes incorporate both the induced wealth effects (operating through their effect on consumption) and on the shadow cost of collection time (operating through interactions with collection time). These simulations also take into account the censoring effects, unlike the last columns of Tables 5 and 11, which simply simulate the effect on the latent collection levels rather than the actual ones. In other words, they predict switches between collecting

\footnotetext{
${ }^{15}$ The size of the terai sample was small - less than 400 households — which is why we do not report that regression here. Nevertheless the results for that sample do not differ materially from those suggested by the third column of Table 14 .
} 
and not collecting firewood, over and above changes in levels of collections for those that collect.

The results show that changes in consumption result in almost equiproportionate changes in collection levels per household, with negligible switching effects. Changes in village population resulting from changes in the number of households (holding household size fixed) have negligible switching effects and on per household collections, implying almost equiproportionate changes in total collections at the village level. Changes in household size have moderate effects on collections per household, with an elasticity in the range .3- .6. These results suggest that rising consumption standards and population levels witnessed in the terai region of Nepal can account for the massive deforestation reported there since the 1950s. The effects with respect to consumption changes are of course opposite to what the $\mathrm{PEH}$ would predict, via the effect of growth in reducing poverty. In contrast to falling dependence on firewood predicted by $\mathrm{PEH}$, our results suggest a sharp increase instead the result of the wealth effect at the household level, possibly compounded at the village level by weakening collective action to regulate firewood collection.

Table 15 however offers one sobering conclusion concerning the process of development on firewood dependence. If the growth process is accompanied by spread of education and diversification into nonfarm occupations, the effect of rising consumption standards could be substantially moderated. The effect of every household head acquiring primary education (i.e., education upto the 5 th grade) would result in a massive reduction in dependence on firewood, which would more than outweigh the effect of upto $40 \%$ growth in consumption standards.

\section{Related Literature}

A large body of literature documents the significant ECPR reliance of the poor, relative to their own consumption (e.g., see the survey by Beck and Nesmith (2001), or various studies of Jodha $(1986,1992,1995))$. This however does not speak to how this dependence changes with a rise in consumption, the central concern of the PEH or EKC. Some studies do show 
that the proportion of consumption accounted by ECPRs is higher for the poor compared with non-poor households. Yet PEH or EKC hypotheses concern the change in ECPR use in absolute terms, not in proportion to consumption. A falling proportion is consistent with a rising dependence on ECPRs in absolute terms. An additional drawback of much of the empirical literature concerning CPRs is that it utilizes cross-sectional data at the level of villages or communities, rather than households (e.g., Agrawal and Yadama (1997), Bardhan (2000), Varughese (2000)). As we have argued above, cross-village evidence is subject to potential problems of endogeneity, whereby poverty may be a consequence of deforestation, or of other unobserved factors (such as topography or soil conditions) that affect both the level of local poverty and the state of neighbouring forests.

Chaudhuri and Pfaff (2002) and Foster and Rosenzweig (2002) estimate Engel relationships concerning ECPRs using household level data with village fixed effects, for Pakistan and India respectively. Chaudhuri and Pfaff find an inverse U-shaped relation (consistent with the EKC hypothesis) between firewood use and incomes in the 1991 Pakistan household data (which combines rural and urban households), while Foster and Rosenzweig find a small (but statistically significant) negative effect in cross-sectional Indian rural household data from 1982. The differences between these countries may arise from different access to alternative fuels, education levels and levels of per capita income. For instance, the switch to modern fuels in Pakistan identified by Chaudhuri and Pfaff occurs particularly among urban households, where fuel substitutes are more easily available than rural areas. Even within rural households there was significant use of kerosene and electricity in cooking: the proportion of rural households using kerosene and electricity for cooking in Pakistan was $90 \%$ and $58 \%$ respectively, compared with $3 \%$ and $1.4 \%$ in Nepal. Educational levels in rural Pakistan were substantially above those in Nepal: e.g., the average years of schooling of household heads in the rural Pakistan sample was 6.3 years, in comparison to 1.87 years in the rural Nepal sample. Moreover, some of our estimated conditional regressions also showed an inverse- $U$ tendency at the top end of the distribution. This suggests that the environmental Kuznets curve may apply in Nepal, but most of the households in our sample were operating on the upward sloping segment.

Other literature on firewood collection in Nepal stresses the role of nonagricultural labor 
markets and forest property rights in specific parts of the country. Amacher, Hyde and Kanel (1996) and Bluffstone (1995) discuss evidence concerning significant elasticities of labor supply and fuelwood collection activities of Nepalese households with respect to shadow wages in the low lying terai region, though not at higher altitudes. This is consistent with our findings concerning the impact of nonfarm employment opportunities. Edmonds (2002) finds a robust $11-14 \%$ reduction in .rewood collection at the household level with respect to formation of forest user groups in the LSMS data for the Arun Valley (which covers three districts in Eastern Nepal that came under the Nepal-United Kingdom Community Forestry Project, out of 75 districts in all of Nepal). In contrast our results which apply to the entire LSMS sample finds negligible effects of forest user groups. In a related paper, Edmonds (2000) finds that the effect of the forest user groups varies substantially with the type and source of external development assistance in different parts of Nepal, and that it was implemented most effectively in the Arun Valley. The difference between our results and Edmonds' may therefore owe to differences in geographical area covered.

\section{Concluding Comments}

Our analysis suffers from a number of shortcomings, many of which stem from the nature of the data we used. The results are based on cross-sectional differences across households and village at a point of time, whose relevance to understanding shifts over time is difficult to assess. The use of panel data over time would be a big step forward. Other data limitations concern absence of information on forest stock and quality: do differences in firewood collection levels drive deforestation? Or are other factors, such as household demand for timber, changes in forest area resulting from conversion to agricultural land, private concessions to timber merchants, and illegal felling more important? To assess this question we would need data concerning changes in forest stock over time, for instance from land satellite images or forest surveys.

The Nepal LSMS data is poor with respect to information concerning prices and availability of fuel substitutes and complements to firewood: the responses contain many missing values which shrink the sample size considerably and were not included in the regressions 
to avoid possible sample selection biases. Understanding the process by which the extent of substitutability among alternative energy sources is expanded is of crucial policy importance. The process of modernization can conceivably be modified by policies of expanding transport networks, and increasing availability of fuel substitutes.

Little or no information was available concerning informal collective action governing use of forest products, forcing us to rely on imperfect proxies. Information concerning membership in forest user groups was also not available. This prevented analysis of the extent and effectiveness of local collective action in limiting firewood collections.

In our ongoing extension of this project to villages in the Indian Himalayas, we are attempting to gather better information on all these dimensions. Contrasting the experience of different Indian states, and of these with Nepal will also be interesting. It is important to reiterate that the patterns observed in Nepal may not be representative of resource problems in other developing countries; it is necessary to extend our analysis to the contexts of alternative resources and alternative countries before any general conclusions can be drawn. 


\section{REFERENCES}

Agrawal A. and G.N. Yadama (1997), 'How Do Local Institutions Mediate Market and Population Pressures on Resources? Forest Panchayats in Kumaon, India,' Development and Change, 28, 435-465.

Amacher G.S., W.F. Hyde and K.R. Kanel (1996), 'Household Fuelwood Demand and Supply in Nepal's Tarai and Mid-Hills: Choice Between Cash Outlays and Labor Opportunity, World Development, Vol. 24, No. 11, pp 1725-1736.

Baland J-M and J-P Platteau (1996), Halting Degradation of Natural Resources: Is There a Role for Rural Communities? Clarendon Press, Oxford.

(1997), 'Wealth Inequality and Efficiency in the Commons Part I: The Unregulated Case,' Oxford Economic Papers 49, 451-482

Barbier E.B. (1997a), 'The Economic Determinants of Land Degradation in Developing Countries,' Philosophical Transactions of the Royal Society, 352, 891-899.

- - (1997b), 'Introduction to the Environmental Kuznets Curve Special Issue,' Environment and Development Economics, 2(4):369-81.

- (1998), 'The Concept of Sustainable Economic Development', and 'Natural Capital and the Economics of Environment and Development,' in The Economics of Environment and Development: Selected Essays, Cheltenham: Edward Elgar.

- (1999), Contribution to Session G1b. Effects of Deforestation and Degradation on Poverty; Co-location of Deforestation and Poverty Due to Common Causal Factors, Workshop on Poverty, Environment and Growth-Oriented Policies, World Bank, Washington DC, 24-25 March 1999.

Bardhan P. (2000), 'Water Community: An Empirical Analysis of Cooperation on Irrigation in South India', Economic Development and Cultural Change, 48, 847-66. 
Bardhan P. and J. Dayton-Johnson (1997), 'Inequality and Conservation on the Local Common: a Theoretical Perspective,' mimeo, Department of Economics, University of California at Berkeley. Forthcoming, Economic Journal.

Beck, T. and Cathy Nesmith, (2001): 'Building on Poor People's Capacities. The Case of Common Property Resources in India and West Africa.', World Development 29(1).

Bluffstone R. (1995), 'The Effect of Labor Market Performance on Deforestation in Developing Countries under Open Access: An Example from Rural Nepal,' Journal of Environmental Economics and Management, vol. 29, 42-63.

Chaudhuri S. and Pfaff A.S.P. (2002), 'Economic Growth and the Environment: What Can we Learn from Household Data?', mimeo, Department of Economics, Columbia University.

Durraiappah, A.K., (1998): 'Poverty and Environmental Degradation: A Review and Analysis of the Nexus,' World Development, Vol. 26, No. 12, pp. 2169-2179.

Edmonds E. (2000) 'Development Assistance and Institutional Reform,' mimeo, Dartmouth College Department of Economics.

- (2002), 'Government-initiated Community Resource Management and Local Resource Extraction from Nepal's Forests,' Journal of Development Economics, 68(1), $89-116$.

Efron B. and Tibshirani R. J. (1993), An Introduction to the Bootstrap, Chapman and Hall, New York.

Foster A. and M. Rosenzweig (2002), 'Economic Growth and the Rise of Forests,' mimeo, Department of Economics, Brown University.

Grossman G. and A. Krueger (1995), 'Economic Growth and the Environment,' Quarterly Journal of Economics, 110: 353-377/

Honore B. (1992), 'Trimmed LAD and Least Squares Estimation of Truncated and Censored Regression Models with Fixed Effects,' Econometrica 60(3), 533-566. 
Jalal K.F. (1993), 'Sustainable Development, Environment and Poverty Nexus,' Asian Development Bank Economics and Development Resoucre Center Occasional Papers No. 7, Manila.

Jodha, N.S. (1986): 'Common Property Resources and Rural Poor in Dry Regions of India,' Economic and Political Weekly, vol XXI No. 27, July 51986.

(1992): 'Common Property Resources: A Missing Dimension of Development Strategies', World Bank Discussion Paper No. 169.

(1995): 'Environmental Crisis and Unsustainability in Himalayas: Lessons from the Degradation Process', in Hanna, S. and Munasinghe, M. (eds.): Property Rights in a Social and Ecological Context. Case Studies and Design Applications. Stockholm: Beijer International Institute of Ecological Economics, World Bank, Washington D.C, pp. 183-206.

Kumar, S.K. and D. Hotchkiss (1988), 'Consequences of Deforestation for Women's Time Allocation, Agricultural Production, and Nutrition in Hill Areas of Nepal,' International Food Policy Research Institute Research Report 69, Washington DC.

Kyriazidou E. (1997),'Estimation of a Panel Data Sample Selection Model,' Econometrica, 65(6), November 1997, 1335-64.

Lele S.M.(1991), 'Sustainable Development: A Critical Review,' World Development, Vol 19, No. 6, pp 607-621.

Lopez R.(1998), 'Where Development Can or Cannot Go: The Role of Poverty-Environment Linkages,' in 1997 Annual World Bank Conference in Development Economics, B. Pleskovic and J. Stiglitz (ed.), Washington D.C.: World Bank.

Maddala G.S.(1987), 'Limited Dependent Variable Methods Using Panel Data," Journal of Human Resources, 22 (3), 307-338.

Mahapatra R. (2000), 'Community Forest Management: The Nepalese Experience,' Down to Earth, Feb 29, 2000, pp. 31-46. 
Maler K.G. (1998), 'Environment, Poverty and Economic Growth,' in 1997 Annual

World Bank Conference in Development Economics, B. Pleskovic and J. Stiglitz (ed.), Washington D.C.: World Bank.

Metz J.J. (1991), 'A Reassessment of the Causes and Severity of Nepal's Environmental Crisis,' World Development, Vol 19, No. 7, pp 805-820.

Myers N. (1986), 'Environmental Repercussions of Deforestation in the Himalayas,' Journal of World Forest Resource Management 2, 63-72.

Yandle B., M. Vijayaraghavan and M. Bhattarai (2002), 'The Environmental Kuznets

Curve: A Primer,' Working Paper, Political Economy Research Center, Center for Free Market Environmentalism, Montana (available at http://www.perc.org/publications/research/kuznets.html)

Varughese, G. (2000), 'Population and Forest Dynamics in the Hills of Nepal: Institutional Remedies by Rural Communities,' in C. Gibson, M. McKean and E. Ostrom (Edited), People and Forests: Communities, Institutions and Governance, Cambridge, MA: MIT Press.

\section{Acknowledgement}

We thank Giovanna Prenuschi, the Central Bureau of Statistics in Nepal and the Poverty and Human Resource Division of the World Bank for making the LSMS data available to us. For useful comments we are grateful to Judy Dean, Eric Edmonds, Marcel Fafchamps, Andy Foster, Bo Honore, Larry Kotlikoff, Sylvie Lambert, Kaivan Munshi, Mark Rosenzweig, Forhad Shilpi, Chris Udry, participants at the September 2001 Santa Fe Institute conference on Inequality, Collective Action and Environmental Sustainability, and at the January 2002 Costa Rica meetings of the MacArthur Inequality network. Shiv Saini, Amaresh Tiwari and Nobuo Yoshida provided excellent and untiring research assistance. Alfredo Cuecuecha also provided useful support. This research was supported by the National Science Foundation (NSF grant no. SES-0079079) and the MacArthur Foundation network on Inequality and Economic Performance. Baland was also supported by the Belgian Program on Interuniversity Poles of Attraction initiated by the Belgian State, Prime Minister's Office, Science Policy Programming. 


\section{Appendix A: Details of Derivation of Best Response Equation}

The household earns income from allocating family labor across different occupations: $j=1,2,3,4,5$ respectively denote (1) self-employment in agriculture, (2) wage labor in agriculture, (3) wage labor in non-agriculture, (4) self-employment in nonagriculture, and (5) self-employment in livestock grazing and fodder collection. The latter activity is complementary with collecting firewood. For simplicity we shall assume that firewood collection and livestock grazing are perfectly complementary activities. Besides the above activities, time is allocated to firewood collection $t_{i v} \equiv T_{i v} F_{i v}$ and leisure $l_{i v}$. The total stock of labor of the household is measured by family size (the number of adults plus half the number of children in adult equivalent units); with a slight abuse of notation we shall denote this by $s_{i v}$. The labor allocated to occupation $j$ is denoted $s_{i v}^{j}$, so the time allocation constraint is (given $\left.s_{i v}^{5} \equiv t_{i v}:\right)$

$$
s_{i v}=\sum_{j=1}^{4} s_{i v}^{j}+l_{i v}+t_{i v}
$$

The budget constraint is given by

$$
\begin{gathered}
E_{i v}=y^{1}\left(s_{i v}^{1} ; \theta_{i v}^{1}, e_{i v}, p_{v}, a_{v}\right)+w_{v}^{2} s_{i v}^{2}+w_{v}^{3} s_{i v}^{3}+y^{4}\left(s_{i v}^{4} ; \theta_{i v}^{4}, e_{i v}, p_{v}, a_{v}\right)+y^{5}\left(t_{i v} ; \theta_{i v}^{5}, p_{v}, a_{v}\right) \\
-c_{v}^{f} F_{i v}
\end{gathered}
$$

where $y^{1}, y^{4}, y^{5}$ are the returns to agriculture, nonfarm business, and livestock activity, which respectively depend (apart from labor allocated) on land $\left(\theta_{i v}^{1}\right)$, education $e_{i v}$, nonfarm business assets $\left(\theta_{i v}^{4}\right)$ and livestock $\left(\theta_{i v}^{5}\right)$ owned by the household. The returns to wage labor are given by the corresponding wage rates $w_{v}^{2}, w_{v}^{3}$ in neighboring agricultural and nonagricultural labor markets. The returns to various self-employed activities also depend on village infrastructure $a_{v}$ and prices $p_{v}$. Finally, $c_{v}^{f}$ denotes the expected fee that the household has to pay a forest guard for collecting one unit of firewood. This depends on the nature of forest property rights and their enforcement (including probability of the collection being monitored and the fees that have to be paid in that event), either by the government or the community itself.

Household $i$ in village $v$ has a given set of characteristics $\theta_{i v} \equiv\left(s_{i v}, \theta_{i v}^{1}, e_{i v}, \theta_{i v}^{4}, \theta_{i v}^{5}\right)$, collection time per unit of firewood $T_{i v}$, and takes as given village variables $\frac{F_{v}}{n_{v}}, W_{v} \equiv\left(p_{v}, w_{v}^{2}, w_{v}^{3}, a_{v}, c_{v}^{f}\right)$. It selects firewood collection $F_{i v}$ and labor allocation $l_{i v}, s_{i v}^{j}, j=1, \ldots, 5$ to maximize utility (2) subject to constraints (11) and (12).

The marginal cost of firewood collection is the opportunity cost of the collection time, plus any fees paid:

$$
M C_{i v}=c_{i v}^{l} T_{i v}+c_{v}^{f}
$$


where $c_{i v}^{l}$ denotes the shadow cost of time for the household. Since households always consume positive leisure, this shadow cost equals the marginal utility of leisure:

$$
c_{i v}^{l}=\frac{\partial w\left(F_{i v}, L_{i v}-\sum_{j} s_{i v}^{j} ; p_{v}, E_{i v}, s_{i v}\right)}{\partial L_{i v}}
$$

Assuming separability of utility between leisure and and other arguments entering the utility function, the marginal utility of leisure is a function only of the quantity of leisure $L_{i v}-\sum_{j=1}^{4} s_{i v}^{j}$. Taking a linear approximation, we obtain

$$
c_{i v}^{l}=\kappa_{1}+\kappa_{2}\left[s_{i v}-F_{i v} T_{i v}-\sum_{j=1}^{4} s_{i v}^{j}\right]+e_{i v}^{\prime}
$$

where $e_{i v}^{\prime}$ denotes a zero mean approximation error, and $\kappa_{1}>0, \kappa_{2}<0$. The right-hand-side of (15) includes time allocated to farm and nonfarm income earning activities which are determined simultaneously with firewood collection. In the reduced form version of the model the allocated times will be a function of household characteristics: a household with more farm or nonfarm assets would devote more time to those activities (under the plausible assumption of complementarity between asset ownership and returns from the corresponding occupation), thus reducing time available for collecting firewood, grazing livestock and other household tasks. Conversely a household with more livestock would ceteris paribus allocate less time to farm and nonfarm earning activities, leaving more time for grazing livestock and collecting firewood. We can then express the shadow cost as a function of time collecting firewood and household characteristics:

$$
c_{i v}^{l}=\delta_{1}+\delta_{3} s_{i v}+\delta_{4} F_{i v} T_{i v}+\delta_{5} \theta_{i v}+V_{v}+e_{i v}^{\prime \prime}
$$

where the coefficient $\delta_{5}$ is expected to be positive with respect to farm or nonfarm assets, and negative with respect to livestock owned. In the event of nonseparability between leisure and consumption (wherein rising consumption raises the value of leisure), this equation generalizes to:

$$
c_{i v}^{l}=\delta_{1}+\delta_{2} E_{i v}+\delta_{3} s_{i v}+\delta_{4} F_{i v} T_{i v}+\delta_{5} \theta_{i v}+V_{v}+e_{i v}^{\prime \prime}
$$

where $\delta_{2}>0$.

The marginal cost of collection for the household then reduces to

$$
\begin{aligned}
M C_{i v} & =c_{v}^{f}+T_{i v}\left[\delta_{1}+\delta_{2} E_{i v}+\delta_{3} s_{i v}+\delta_{4} F_{i v} T_{i v}+\delta_{5} \theta_{i v}+V_{v}+e_{i v}^{\prime \prime}\right] \\
& =c_{v}^{f}+\delta_{1} T_{i v}+\delta_{4} T_{i v}^{2} F_{i v}+\delta_{2} E_{i v} T_{i v}+\delta_{3} s_{i v} T_{i v}+\delta_{5} \theta_{i v} T_{i v}+\delta_{6} V_{v} T_{i v}+e_{i v}^{3} .
\end{aligned}
$$


Equating with marginal utility, we obtain the best response equation

$$
\begin{aligned}
F_{i v}= & \frac{1}{-\alpha_{1}-\alpha_{4}+\delta_{4} T_{i v}^{2}}\left[\alpha_{0}+\alpha_{21} E_{i v}+\alpha_{22} E_{i v}^{2}+\alpha_{3} s_{i v}+\alpha_{4} \frac{F_{v}}{n_{v}}+\alpha_{v}^{\prime}-c_{v}^{f}-\delta_{0} T_{i v}\right. \\
& \left.-\delta_{2} E_{i v} T_{i v}-\delta_{3} s_{i v} T_{i v}-\delta_{5} \theta_{i v} T_{i v}-\delta_{6} V_{v} T_{i v}-e_{i v}^{3}\right]
\end{aligned}
$$

Taking a linear approximation to $\frac{1}{-\alpha_{1}-\alpha_{4}+\delta_{4} T_{i v}^{2}}$, the best response can be represented as

$$
\begin{aligned}
F_{i v}= & \beta_{0}+\beta_{21} E_{i v}+\beta_{22} E_{i v}^{2}+\beta_{3} s_{i v}+\beta_{5} T_{i v}+\beta_{6} T_{i v}^{2}+\beta_{7} E_{i v} T_{i v}+\beta_{8} \theta_{i v} T_{i v} \\
& +\left(\beta_{4} \frac{F_{v}}{n_{v}}+W_{v}\right)+e_{i v}^{4}
\end{aligned}
$$

where $W_{v}$ is a village effect that incorporates common village influences on utility (such as climate) and cost (such as collection charges) of firewood, and the error term $e_{i v}^{4}$ absorbs all the ignored interaction and higher order terms resulting from the linear approximation. ${ }^{16}$

\footnotetext{
${ }^{16}$ In particular, we have dropped the interaction between collection time and household size or composition, which may be believed to be important a priori. These interaction effects turned out to be insignificant, so we dropped them to minimize collinearity with the household stock/composition levels.
} 


\section{Appendix B: Estimation Procedure for IntraVillage Censored Regression}

The best response equation (5) includes censoring and village fixed effects. The nonlinearity of the model precludes estimating the model in first differences which washes out the village fixed effects. Accordingly we rely on the semiparametric estimator proposed by Honore (1992) for this purpose. We call it PANTOB. The problem with implementing this estimator are twofold.

First, households that do not collect any firewood do not report collection times (that they would have encountered had they chosen to collect). Thus incorporation of such households in the estimating sample (necessary to avoid sample selection biases) requires us to use a proxy for their collection times. Since information concerning other characteristics of these households are available, we can predict collection times based on observed household characteristics. Accordingly we postulate

$$
T_{i v}=\lambda_{1} \theta_{i v}+\lambda_{2} Z_{i v}+\lambda_{v}+\eta_{i v}^{1}
$$

where $\theta_{i v}$ represents vector of household assets owned, and $Z_{i v}$ a vector of instruments uncorrelated with the error term in the firewood equation (5). It is plausible that proximity to the forest will be correlated with ownership of farm and nonfarm business assets in ways that depend on the precise topography of these villages (e.g., those with nonfarm business assets may be located closer to market areas which may be on the opposite side of the village from where the forest lie, so such households may incur higher collection times). For instruments $Z_{i v}$ we include ethnicity and migratory status which do not affect utility or cost of collecting firewood per se after controlling for levels of consumption, asset ownership and household size that enter the firewood equation. But they may affect location patterns owing to patterns of ethnic segregation of housing within the village. The fixed effect in (21) captures the village level effects arising from historical forest stock and proximity, and steady state extraction activities of villagers that were incorporated in (3).

To estimate the coefficients of (21), we encounter the endogenous sample selection problem: the dependent variable is observed only for those who collect firewood, so the sample is probably biased in favor of those with low collection times. The selection equation is provided by the firewood equation: collection times are observed for those with

$$
\begin{aligned}
F_{i v}^{*} \equiv \quad & \beta_{0}+\beta_{21} E_{i v}+\beta_{22} E_{i v}^{2}+\beta_{3} s_{i v}+\beta_{5} T_{i v} \\
& +\beta_{6} T_{i v}^{2}+\beta_{7} E_{i v} T_{i v}+\beta_{8} \theta_{i v} T_{i v}+\left(\beta_{4} \frac{F_{v}}{n_{v}}+W_{v}\right)+e_{i v}^{4} \\
&
\end{aligned}
$$


This is a sample selection model with fixed effects, for which we use the estimator proposed by Kyriazidou (1997). In this procedure, a first round set of consistent estimates of $\lambda_{1}$ and $\lambda_{2}$ is obtained from a conditional logit for the sample selection model implied by equations (21) and (22). At the second stage a weighted least squares panel regression of (21) is estimated, where the weights vary with the estimated degree of sample selection bias and are constructed on the basis of the first round estimates of $\lambda_{1}, \lambda_{2}$.

The estimated $\lambda_{1}, \lambda_{2}$ coefficients can then be used to obtain a consistent estimate of the village fixed effect $\lambda_{v}$ for those villages containing at least one collector:

$$
\hat{\lambda}_{v}=\frac{\sum_{i \in C_{v}}\left(T_{i v}-\hat{\lambda}_{1} \theta_{i v}-\hat{\lambda}_{2} Z_{i v}\right)}{N C_{v}}
$$

where $C_{v}$ denotes the set of collecting households in village $v$, and $N C_{v}$ the number of such households. We then predict the collection times for noncollectors using the estimated coefficients of (21) and their observed characteristics $\theta_{i v}, Z_{i v}$. These households can be included in estimation of (5) with their predicted collection time proxying for their actual collection time.

The second problem with using PANTOB is that it assumes all right-hand-side explanatory variables are exogenous. As explained above, the exogeneity of consumption is a dubious assumption in a context with so much self-employment. So we use a set of instruments $I_{i v}$ to predict consumption, apart from asset ownership and household demographics:

$$
E_{i v}=\nu_{1}+\nu_{2} \theta_{i v}+\nu_{3} s_{i v}+\nu_{4} I_{i v}+\nu_{v}+\eta_{i v}^{2}
$$

This amounts to using a measure of permanent consumption in the firewood regression, since unsystematic transitory shocks belong to the error term of the above equation. The instrument set includes ethnic status, age of head of household, education and occupation of the father of the head, and value of land inherited by the head, which are plausibly uncorrelated with the residual in the firewood collection equation (5) after controlling for the households consumption and other characteristics that enter it. ${ }^{17}$ When consumption is instrumented in this way, it modifies the sample selection equation as a function of the household's characteristics (i.e., when combined with (21)) so this necessitates re-estimating the coefficients of (21). Following this, we obtain the coefficients of the collection equation (5) upon applying PANTOB to the data using the predicted collection times for noncollectors (using the estimated coefficients of (21), and consumptions predicted by the estimated coefficients of (24). The PANTOB standard errors underestimate the true standard errors

\footnotetext{
${ }^{17}$ Estimation of (24) is mercifully not subject to any censoring biases, and reveals ethnic status, parental literacy, occupation and age of the head to be significant determinants of consumption.
} 
for not incorporating the fact that collection times and consumption levels are subject to prediction error. We therefore bootstrap in order to estimate the additional variability of PANTOB's estimates due to variability in the estimates of coefficients of (21) and (24). ${ }^{18}$

\section{Appendix C: Estimation Procedure for Inter Village Censored Regression}

Combining (8) and (9), we obtain the following expression for village average collection levels:

$$
\frac{F_{v}}{n_{v}}=\beta_{0}^{\prime}+\left[\boldsymbol{\sigma}_{1}+\boldsymbol{\beta}^{\prime}\right] \cdot \boldsymbol{\omega}_{v}+\boldsymbol{\sigma}_{2}^{\prime} \cdot \boldsymbol{\phi}_{v}+\varepsilon_{v}^{\prime}
$$

where primed variables are obtained from unprimed ones upon premultiplying by $\frac{1}{1-\beta_{4}}$.

Equation (25) can be estimated from a cross-village regression. Alternatively, we can utilize household level information rather than village averages of collection levels. Note that the village effect in the household response equation (7) equals $K_{v} \equiv W_{v}+\beta_{4} \frac{F_{v}}{n_{v}}$. Utilizing (9) and (25), this village effect can be expressed as

$$
K_{v}=\psi_{0}+\boldsymbol{\psi}_{1} \cdot \boldsymbol{\omega}_{v}+\boldsymbol{\psi}_{2} \cdot \boldsymbol{\phi}_{v}+\xi_{v}
$$

where the residual $\xi_{v}$ is uncorrelated with $\boldsymbol{\omega}_{v}$ and $\phi_{v}$, on the basis of the assumption that the same is true of $\varepsilon_{v}$. An estimate of the village effect is then contained in the estimated residual for each household:

$$
\hat{e}_{i v}^{4} \equiv F_{i v}-\hat{\boldsymbol{\beta}} \cdot \omega_{i v}=\beta_{0}+K_{v}+e_{i v}^{4}+e_{i v}^{5}
$$

where $\hat{\boldsymbol{\beta}}$ denotes coefficients estimated from the household level regression, and $e_{i v}^{5} \equiv[\hat{\boldsymbol{\beta}}-\boldsymbol{\beta}] . \omega_{i v}$ is the result of estimation error of household coefficients. Combining this with (26) we obtain

$$
\hat{e}_{i v}^{4}=\beta_{0}+\psi_{0}+\boldsymbol{\psi}_{1} \cdot \boldsymbol{\omega}_{v}+\boldsymbol{\psi}_{2} \cdot \boldsymbol{\phi}_{v}+\xi_{v}+e_{i v}^{4}+e_{i v}^{5}
$$

\footnotetext{
${ }^{18}$ In particular, let $\theta_{2}$ denote the vector of estimates from PANTOB and $\theta_{1}$ denote the vector of estimates prior to it. Then the variance of $\theta_{2}$, denoted $V\left(\theta_{2}\right)$ can be decomposed as $E\left(V\left(\theta_{2} \mid \theta_{1}\right)\right)+V\left(E\left(\theta_{2} \mid \theta_{1}\right)\right)$. PANTOB provides a consistent estimate of the first term. The sample analog of the second term is obtained by bootstrapping. This procedure treats the data as constituting the population base, with samples of the same size drawn from it with replacement. The sampling scheme retained the panel structure of the original dataset, where villages were redrawn repeatedly. Estimates were computed with the drawn samples and used to compute measures of variability. Five hundred and fifty samples were drawn; the standard errors stabilized with respect to the number of samples drawn. For further details of this bootstrapping procedure see Efron and Tibshirani (1993).
} 
a regression which can be run at the household level. This utilizes the fact that each household's collection within a village provides an independent estimate of the common village effect.

Estimation of (28) will however have to incorporate censoring of collections at the household level. In particular, the estimated residual in the presence of censoring is

$$
\hat{e}_{i v}^{4} \equiv F_{i v}-\hat{\boldsymbol{\beta}} \cdot \omega_{i v}=\max \left[-\hat{\boldsymbol{\beta}} \cdot \omega_{i v}, \varphi_{0}+\boldsymbol{\psi}_{1} \cdot \boldsymbol{\omega}_{v}+\boldsymbol{\psi}_{2} \cdot \boldsymbol{\phi}_{v}+\xi_{v}+e_{i v}^{4}+e_{i v}^{5}\right] .
$$

The parameters $\boldsymbol{\psi}_{i}$ in (29) are estimated by maximum likelihood with random village effects $\xi_{v}$, using a random effects tobit estimator (Maddala (1987)) modified to accommodate a nonzero truncation point. This assumes Gaussian distributions for $\xi_{v}, e_{i v}^{4}, e_{i v}^{5}$, and independence from distributions of included variables $\boldsymbol{\omega}_{v}, \boldsymbol{\phi}_{v}$. The independence assumption is valid if all relevant village level determinants of utility, cost of firewood and collective action have been included. To control for potential endogeneity biases that may result from violations of this assumption, we instrument for village averages of consumption and collection times in estimation of (29), using village averages of their corresponding instruments used at the household level, besides geography and infrastructure variables that are unlikely to have a direct effect on firewood collections. ${ }^{19}$

\footnotetext{
${ }^{19}$ In particular, instruments with significant predictive power for mean consumption include mean value of inherited land, fraction of residents in middle and low castes, average hours of supply of electricity per week, distance to agricultural extension service centers, latitude and longitude. For mean collection time relevant instruments include electricity supply, mean literacy of parents of household heads, and mean age of household heads.
} 
TABLE 1: Household Characteristics: Descriptive Statistics

\begin{tabular}{|c|c|c|c|c|c|c|}
\hline Variable & $\begin{array}{l}\text { Number of } \\
\text { Observations }\end{array}$ & $\begin{array}{c}\text { Number of } \\
\text { Zeroes }\end{array}$ & Mean & $\begin{array}{l}\text { Standard } \\
\text { Deviation }\end{array}$ & Minimum & Maximum \\
\hline $\begin{array}{l}\text { Firewood Collected } \\
\text { (bharis/month) }\end{array}$ & 2670 & 807 & 5.78 & 5.76 & 0 & 35 \\
\hline $\begin{array}{l}\text { Collection Time } \\
\text { (hrs per bhari) }\end{array}$ & 1858 & 0 & 5.04 & 2.74 & 0.17 & 14 \\
\hline $\begin{array}{l}\text { Annual Consumption } \\
\text { Expenditure (Rs.) }\end{array}$ & 2712 & 0 & 35309 & 27630 & 2869 & 445936 \\
\hline $\begin{array}{l}\text { Value of Cultivable } \\
\text { Land (Rs.) }\end{array}$ & 2348 & 685 & 145736 & 588266 & 0 & 17500000 \\
\hline $\begin{array}{l}\text { Value of Non-Farm } \\
\text { Business Assets (Rs.) }\end{array}$ & 2712 & 2260 & 7940 & 73167 & 0 & 25000 \\
\hline $\begin{array}{l}\text { Fraction Labor } \\
\text { Non-Agriculture } \\
\text { (self-employed) }\end{array}$ & 2673 & 2071 & 0.08 & 0.21 & 0 & 1 \\
\hline $\begin{array}{l}\text { Fraction Wage Labor } \\
\text { Agriculture }\end{array}$ & 2673 & 1590 & 0.15 & 0.25 & 0 & 1 \\
\hline $\begin{array}{l}\text { Fraction Wage Labor } \\
\text { Non-Agriculture }\end{array}$ & 2673 & 1705 & 0.11 & 0.20 & 0 & 1 \\
\hline $\begin{array}{l}\text { Number of } \\
\text { Cows Owned }\end{array}$ & 2439 & 241 & 3.72 & 3.12 & 0 & 27 \\
\hline $\begin{array}{l}\text { Household Size } \\
\text { (Adult Equiv.) }\end{array}$ & 2712 & 25 & 4.41 & 2.06 & 0.00 & 20.4 \\
\hline $\begin{array}{l}\text { Years Schooling } \\
\text { Household Head }\end{array}$ & 2712 & 1912 & 1.87 & 3.39 & 0 & 17 \\
\hline $\begin{array}{l}\text { Female-Headed } \\
\text { Household }\end{array}$ & 2712 & 2361 & 0.13 & 0.34 & 0 & 1 \\
\hline Fraction Children & 2712 & 741 & 0.26 & 0.20 & 0 & 0.8 \\
\hline $\begin{array}{l}\text { Fraction Prime-Age } \\
\text { Males }\end{array}$ & 2712 & 133 & 0.35 & 0.18 & 0 & 1 \\
\hline $\begin{array}{l}\text { Fraction Prime-Age } \\
\text { Females }\end{array}$ & 2712 & 69 & 0.35 & 0.17 & 0 & 1 \\
\hline Fraction Old Men & 2712 & 2423 & 0.02 & 0.08 & 0 & 1 \\
\hline $\begin{array}{l}\text { Upper Caste } \\
\text { (Brahmin-Chetry) }\end{array}$ & 2710 & 1756 & 0.35 & .48 & 0 & 1 \\
\hline $\begin{array}{l}\text { Middle Caste } \\
(\text { Magar-Lumbu) }\end{array}$ & 2710 & 1962 & 0.28 & 0.45 & 0 & 1 \\
\hline Low Caste & 2710 & 2477 & 0.09 & 0.28 & 0 & 1 \\
\hline Hindu & 2710 & 357 & 0.87 & 0.34 & 0 & 1 \\
\hline Buddhist & 2710 & 2535 & 0.06 & 0.25 & 0 & 1 \\
\hline Muslim & 2710 & 2614 & 0.04 & 0.18 & 0 & 1 \\
\hline $\begin{array}{l}\text { Other Non-Hindu } \\
\text { Religion }\end{array}$ & 2710 & 2680 & 0.01 & 0.10 & 0 & 1 \\
\hline $\begin{array}{l}\text { Migration into Village } \\
\text { for Non-Economic Reasons }\end{array}$ & 2712 & 2420 & 0.11 & 0.31 & 0 & 1 \\
\hline Time to Market & 2640 & 14 & 6.4 & 18.07 & 0 & 168 \\
\hline Time to Shop & 2566 & 64 & 0.93 & 4.45 & 0 & 144 \\
\hline
\end{tabular}


TABLE 2: Village Characteristics: Descriptive Statistics

\begin{tabular}{|c|c|c|c|c|c|c|}
\hline Variable & $\begin{array}{c}\text { Number of } \\
\text { Observations }\end{array}$ & $\begin{array}{c}\text { Number of } \\
\text { Zeroes }\end{array}$ & Mean & $\begin{array}{l}\text { Standard } \\
\text { Deviation }\end{array}$ & Minimum & Maximum \\
\hline Mean Consumption (Rs) & 215 & 0 & 35623 & 13783 & 1147 & 99124 \\
\hline Gini Consumption & 215 & 0 & 0.30 & 0.09 & 0.09 & 0.66 \\
\hline Average Poverty Gap (\$1 per day) & 215 & 19 & 0.13 & 0.11 & 0.00 & 0.48 \\
\hline Population & 215 & 0 & 797 & 889 & 42 & 5875 \\
\hline Mean Household Size & 215 & 0 & 4.39 & 0.72 & 2.76 & 6.64 \\
\hline Fraction in Forest User Group & 215 & 125 & .11 & .19 & 0 & 1 \\
\hline Gini Landownership & 208 & 0 & 0.64 & 0.14 & 0.27 & 0.92 \\
\hline Ethnic Fragmentation & 215 & 52 & 0.33 & 0.24 & 0 & 0.74 \\
\hline Religious Fragmentation & 215 & 119 & 0.14 & 0.19 & 0 & 0.75 \\
\hline Mean Collection Time (hrs/bhari) & 184 & 0 & 5.27 & 2.44 & 0.50 & 12.86 \\
\hline Standard Deviation Collection Time & 179 & 0 & 1.78 & 0.88 & 0.00 & 5.95 \\
\hline Average Cows Owned & 215 & 0 & 3.62 & 1.67 & 0.4 & 9.10 \\
\hline Years Schooling Household Head & 215 & 17 & 1.88 & 1.46 & 0 & 7.08 \\
\hline Proportion Female-Headed Household & 215 & 55 & 0.13 & 0.12 & 0 & 0.58 \\
\hline Time to Dirt Road (hrs.) & 208 & 0 & 6.20 & 12.99 & 0.02 & 84.00 \\
\hline Time to Market Center (hrs.) & 215 & 0 & 4.21 & 7.43 & 0.10 & 61.09 \\
\hline Time to Krishi Center (hrs.) & 215 & 0 & 3.21 & 4.23 & 0.13 & 25.62 \\
\hline Time to Paved Road (hrs.) & 205 & 0 & 8.03 & 13.05 & 0.06 & 84.00 \\
\hline Kerosene/Gas Stove Access (dummy) & 215 & 187 & 0.13 & 0.34 & 0 & 1 \\
\hline $\begin{array}{l}\text { Average Agricultural } \\
\text { Yield (Rs. million/acre) }\end{array}$ & 208 & 0 & 0.16 & 0.22 & 0.01 & 1.69 \\
\hline Elevation above sea level (Km) & 215 & 0 & 0.94 & 0.94 & 0.058 & 5.29 \\
\hline Latitude (deg.) & 215 & 0 & 27.69 & 0.84 & 26.42 & 29.75 \\
\hline Longitude (deg.) & 215 & 0 & 84.68 & 2.13 & 80.25 & 88.08 \\
\hline Natural Disaster Dummy & 196 & 87 & 0.56 & 0.50 & 0 & 1 \\
\hline
\end{tabular}

TABLE 3: Fuel Sources

\begin{tabular}{|l|c|c|c|c|c|}
\hline $\begin{array}{l}\text { Percent households } \\
\text { using as }\end{array}$ & wood & cowdung & $\begin{array}{c}\text { leaves and } \\
\text { crop residues }\end{array}$ & kerosene & $\begin{array}{c}\text { others: electricity,gas, } \\
\text { biogas, coal,... }\end{array}$ \\
\hline primary source & 72.8 & 18.4 & 6.1 & 1.7 & 0.9 \\
\hline secondary source & 5.8 & 8.9 & 26.1 & 1.4 & 0.5 \\
\hline
\end{tabular}


TABLE 4: Characteristics of Terai and Non-Terai Regions

\begin{tabular}{|l|c|c|}
\hline & Terai & Non-terai \\
\hline Number of Households & 1054 & 1658 \\
\hline Mean Household Consumption & 34527 & 35805 \\
& $(27437)$ & $(27748)$ \\
\hline Mean Household Size & 4.61 & 4.27 \\
& $(2.25)$ & $(1.96)$ \\
\hline Mean Value & 222528 & 107242 \\
of Cultivated land & $(711717)$ & $(511314)$ \\
\hline Mean Value of & 5768 & 9320 \\
Non-Farm Assets & $(39375)$ & $(88139)$ \\
\hline Mean Years Schooling & 2 & 1.78 \\
of Household Head & $(3.44)$ & $(3.35)$ \\
\hline Mean Number of & 2.98 & 4.14 \\
Cows & $(2.94)$ & $(3.14)$ \\
\hline Mean \% of Time Given to & 22 & 17 \\
Non-Farm Occupations & $(29)$ & $(26)$ \\
\hline Proportion of Households & 0.65 & 0.08 \\
not Collecting & & \\
\hline Mean Collection per & 2.37 & 7.96 \\
Collecting Household & $(4.04)$ & $(5.64)$ \\
\hline Mean Collection Time & 5.0 & 5.03 \\
per Collecting Household & $(3.07)$ & $(2.67)$ \\
\hline & & \\
\hline
\end{tabular}


TABLE 5: OLS Regressions of Collections on Consumption

\begin{tabular}{|l|c|c||c|c|}
\hline & \multicolumn{2}{|c|}{ Intravillage } & \multicolumn{2}{c|}{ Intervillage } \\
\hline Consumption & $12.29^{* *}$ & $81.39^{* * *}$ & 90.21 & 102.91 \\
& $(5.73)$ & $(16.55)$ & $(55.91)$ & $(71.35)$ \\
\hline Consumption Sq. & $-73.04^{* * *}$ & $-1004.19^{* * *}$ & -306.56 & -122.42 \\
& $(23.22)$ & $(247.88)$ & $(260.19)$ & $(1351.24)$ \\
\hline Consumption Cube & & $3426.29^{* * *}$ & & -4332.24 \\
& & $(1201.94)$ & & $(11018.43)$ \\
\hline Consumption 4th power & & $-3526.87^{* *}$ & & 14456.63 \\
& & $(1669.63)$ & & $(25223.29)$ \\
\hline Consumption*Coll. Time & $10.89^{* * *}$ & $10.84^{* * *}$ & -2.47 & -2.35 \\
& $(.63)$ & $(.63)$ & $(3.71)$ & $(3.78)$ \\
\hline \hline Number of Households & 2670 & 2670 & & 142 \\
Number of Villages & 215 & 215 & 142 & .33 \\
(within)- $R^{2}$ & .15 & .16 & & .34 \\
\hline \hline \multicolumn{5}{|c|}{$*$ significant at $10 \%, * *$ significant at 5\%, ***: significant at 1\% } \\
\hline \multicolumn{5}{|c|}{ Standard errors in parentheses } \\
\hline Intervillage regression includes user group fraction, inequality in land and consumption, \\
\hline
\end{tabular}


TABLE 6: Household Panel Latent Firewood Collection Determinants:

Different Specifications

\begin{tabular}{|c|c|c|c|c|}
\hline & 6.1 & 6.2 & 6.3 & 6.4 \\
\hline Variable & $\begin{array}{c}\text { Estimate } \\
\text { (bootstr. std. err.) }\end{array}$ & $\begin{array}{c}\text { Estimate } \\
\text { (bootstr. std. err.) }\end{array}$ & $\begin{array}{c}\text { Estimate } \\
\text { (uncorrected std. err.) }\end{array}$ & $\begin{array}{c}\text { Estimate } \\
\text { (uncorrected std. error) }\end{array}$ \\
\hline Consumption & $\begin{array}{c}77.71 \\
(77.57)\end{array}$ & $\begin{array}{c}59.62 \\
(76.50)\end{array}$ & $\begin{array}{l}34.35^{*} \\
(17.64)\end{array}$ & $\begin{array}{c}48.96 \\
(34.47)\end{array}$ \\
\hline $\begin{array}{l}\text { Consumption } \\
\text { Square }\end{array}$ & $\begin{array}{l}-249.96 \\
(727.83)\end{array}$ & $\begin{array}{l}-409.56 \\
(646.02)\end{array}$ & $\begin{array}{c}17.51 \\
(77.77)\end{array}$ & \\
\hline Collection Time & $\begin{array}{l}-0.15 \\
(0.31)\end{array}$ & $\begin{array}{l}-0.43 \\
(0.33)\end{array}$ & $\begin{array}{l}-0.25 \\
(0.29)\end{array}$ & $\begin{array}{l}-0.17 \\
(0.32)\end{array}$ \\
\hline $\begin{array}{l}\text { Collection Time } \\
\text { Square }\end{array}$ & $\begin{array}{c}0.02 \\
(0.03)\end{array}$ & $\begin{array}{c}0.02 \\
(0.03)\end{array}$ & $\begin{array}{c}0.02 \\
(0.02)\end{array}$ & $\begin{array}{c}0.02 \\
(0.03)\end{array}$ \\
\hline $\begin{array}{l}\text { Consumption* } \\
\text { Collection Time }\end{array}$ & & $\begin{array}{c}8.68 \\
(5.91)\end{array}$ & $\begin{array}{c}1.10 \\
(3.24)\end{array}$ & \\
\hline $\begin{array}{l}\text { Land Owned* } \\
\text { Collection Time }\end{array}$ & $\begin{array}{l}-0.22 \\
(0.15)\end{array}$ & $\begin{array}{l}-0.24^{*} \\
(0.14)\end{array}$ & $\begin{array}{l}-0.23^{*} \\
(0.14)\end{array}$ & $\begin{array}{l}-0.22 \\
(0.15)\end{array}$ \\
\hline $\begin{array}{l}\text { Nonfarm Business Assets* } \\
\text { Collection Time }\end{array}$ & $\begin{array}{l}-0.29^{*} \\
(0.16)\end{array}$ & $\begin{array}{l}-0.36^{*} \\
(0.15)\end{array}$ & $\begin{array}{c}-0.37^{* *} \\
(0.18)\end{array}$ & $\begin{array}{c}-0.29 * * \\
(0.14)\end{array}$ \\
\hline $\begin{array}{l}\text { Cows Owned* } \\
\text { Collection Time }\end{array}$ & $\begin{array}{c}0.01 \\
(0.01)\end{array}$ & $\begin{array}{c}0.01 \\
(0.01)\end{array}$ & $\begin{array}{l}0.02 * \\
(0.01)\end{array}$ & $\begin{array}{c}0.01 \\
(0.01)\end{array}$ \\
\hline $\begin{array}{l}\text { Years Schooling of Head* } \\
\text { Collection Time }\end{array}$ & $\begin{array}{c}-0.03^{* *} \\
(0.01)\end{array}$ & $\begin{array}{l}-0.03^{*} \\
(0.01)\end{array}$ & $\begin{array}{l}-0.02^{*} \\
(0.01)\end{array}$ & $\begin{array}{c}-0.03^{* *} \\
(0.01)\end{array}$ \\
\hline Household Size & $\begin{array}{l}0.95^{* *} \\
(0.42)\end{array}$ & $\begin{array}{l}0.88^{* *} \\
(0.43)\end{array}$ & $\begin{array}{c}0.93^{* * *} \\
(0.30)\end{array}$ & $\begin{array}{l}1.05^{* *} \\
(0.42)\end{array}$ \\
\hline $\begin{array}{l}\text { Household Size } \\
\text { Square }\end{array}$ & $\begin{array}{l}-0.05 \\
(0.03)\end{array}$ & $\begin{array}{l}-0.04 \\
(0.03)\end{array}$ & $\begin{array}{c}0.03 \\
(0.02)\end{array}$ & $\begin{array}{l}-0.05 \\
(0.03)\end{array}$ \\
\hline Fraction Children & $\begin{array}{l}-1.01 \\
(3.56)\end{array}$ & $\begin{array}{l}-1.14 \\
(3.46)\end{array}$ & $\begin{array}{l}-1.40 \\
(3.27)\end{array}$ & $\begin{array}{l}-1.11 \\
(3.61)\end{array}$ \\
\hline $\begin{array}{l}\text { Fraction Prime-Age } \\
\text { Males }\end{array}$ & $\begin{array}{l}-0.45 \\
(3.27)\end{array}$ & $\begin{array}{l}-0.60 \\
(3.17)\end{array}$ & $\begin{array}{l}-0.73 \\
(2.98)\end{array}$ & $\begin{array}{l}-0.52 \\
(3.31)\end{array}$ \\
\hline $\begin{array}{l}\text { Fraction Prime-Age } \\
\text { Females }\end{array}$ & $\begin{array}{c}0.88 \\
(2.84)\end{array}$ & $\begin{array}{c}0.73 \\
(2.74)\end{array}$ & $\begin{array}{c}0.62 \\
(2.67)\end{array}$ & $\begin{array}{c}0.79 \\
(2.88)\end{array}$ \\
\hline Fraction Old Men & $\begin{array}{l}-0.25 \\
(2.97)\end{array}$ & $\begin{array}{l}-0.56 \\
(2.93)\end{array}$ & $\begin{array}{c}0.56 \\
(2.77)\end{array}$ & $\begin{array}{l}-0.07 \\
(2.98)\end{array}$ \\
\hline Female Head & $\begin{array}{l}-0.15 \\
(0.39)\end{array}$ & $\begin{array}{l}-0.13 \\
(0.38)\end{array}$ & $\begin{array}{l}-0.15 \\
(0.38)\end{array}$ & $\begin{array}{l}-0.19 \\
(0.38)\end{array}$ \\
\hline Time to Market & $\begin{array}{c}0.00 \\
(0.01)\end{array}$ & $\begin{array}{l}-0.00 \\
(0.01)\end{array}$ & $\begin{array}{c}0.00 \\
(0.01)\end{array}$ & $\begin{array}{c}0.00 \\
(0.01)\end{array}$ \\
\hline Time to Shop & $\begin{array}{c}-0.03 \\
(.02)\end{array}$ & $\begin{array}{l}-0.02 \\
(0.02)\end{array}$ & $\begin{array}{l}-0.02 \\
(0.02)\end{array}$ & $\begin{array}{l}-0.03 \\
(0.02)\end{array}$ \\
\hline \multicolumn{5}{|c|}{$\begin{array}{l}\text { Consumption instrumented except in Version } 6.3 \\
\text { The }{ }^{*} \text { in the Variable column denotes interactions } \\
\text { No. of observations }=1427 \text {; p-value for chi-sq test for joint significance }=0.00 \\
* \text { : significant at } 10 \%, * * \text { : significant at } 5 \%, * * * \text { : significant at } 1 \%\end{array}$} \\
\hline
\end{tabular}


TABLE 7: Household Panel Latent Firewood Collection Determinants:

Estimated Elasticities Based on Version 1

\begin{tabular}{|c|c|c|c|c|c|}
\hline Variable & $\begin{array}{c}\text { Derivative } \\
\text { (abs. t-value) }\end{array}$ & $\begin{array}{c}\text { Elasticity at } \\
\text { 30th percentile }\end{array}$ & $\begin{array}{c}\text { Elasticity at } \\
\text { Median }\end{array}$ & $\begin{array}{c}\text { Elasticity at } \\
\text { 75th percentile }\end{array}$ & $\begin{array}{c}\text { Effect of one } \\
\text { S.D. increase } \\
(95 \% \text { CI }=+/-)\end{array}$ \\
\hline $\begin{array}{l}\text { Consumption } \\
\text { (Rs. mill.) }\end{array}$ & $\begin{array}{l}62.97 \\
(1.49)\end{array}$ & 1.42 & 0.37 & 0.25 & $\begin{array}{c}1.66 \\
(2.18)\end{array}$ \\
\hline Collection Time & $\begin{array}{c}0.01 \\
(0.13) \\
\end{array}$ & -0.06 & 0.01 & 0.04 & 0.02 \\
\hline Land owned & $\begin{array}{l}-0.89 \\
(0.59)\end{array}$ & -0.00 & -0.01 & -0.01 & $\begin{array}{l}-0.53 \\
(0.68)\end{array}$ \\
\hline Nonfarm assets & $\begin{array}{l}-1.15 \\
(1.78)\end{array}$ & 0.00 & 0.00 & 0.00 & $\begin{array}{l}-0.09 \\
(0.09)\end{array}$ \\
\hline $\begin{array}{l}\text { Number of cows } \\
\text { owned }\end{array}$ & $\begin{array}{c}0.04 \\
(0.97)\end{array}$ & 0.09 & 0.03 & 0.02 & $\begin{array}{c}0.14 \\
(0.28)\end{array}$ \\
\hline Years Schooling Head & $\begin{array}{l}-0.12 \\
(2.24)\end{array}$ & 0.00 & 0.00 & -0.03 & $\begin{array}{l}-0.39 \\
(0.34)\end{array}$ \\
\hline Household Size & $\begin{array}{c}0.57 \\
(2.53) \\
\end{array}$ & 2.18 & 0.48 & 0.25 & $\begin{array}{c}1.14 \\
(0.89) \\
\end{array}$ \\
\hline Fraction Children & $\begin{array}{l}-1.01 \\
(0.28)\end{array}$ & -0.14 & -0.05 & -0.04 & $\begin{array}{l}-0.20 \\
(1.38) \\
\end{array}$ \\
\hline $\begin{array}{l}\text { Fraction Prime-age } \\
\text { Male }\end{array}$ & $\begin{array}{l}-0.44 \\
(0.14)\end{array}$ & -0.11 & -0.03 & & $\begin{array}{l}-0.02 \\
(1.14)\end{array}$ \\
\hline $\begin{array}{l}\text { Fraction Prime-Age } \\
\text { Female }\end{array}$ & $\begin{array}{c}0.88 \\
(0.14)\end{array}$ & 0.22 & 0.06 & 0.04 & $\begin{array}{c}0.14 \\
(0.91)\end{array}$ \\
\hline $\begin{array}{l}\text { Fraction Old } \\
\text { Male }\end{array}$ & $\begin{array}{l}-0.25 \\
(0.09)\end{array}$ & 0.00 & 0.00 & 0.00 & $\begin{array}{l}-0.02 \\
(0.43)\end{array}$ \\
\hline Time to Market & $\begin{array}{c}0.00 \\
(0.07)\end{array}$ & 0.00 & 0.00 & 0.00 & $\begin{array}{c}0.01 \\
(0.34) \\
\end{array}$ \\
\hline Time to Shop & $\begin{array}{l}-0.03 \\
(1.20)\end{array}$ & -0.00 & -0.00 & -0.00 & $\begin{array}{l}-0.14 \\
(0.22)\end{array}$ \\
\hline
\end{tabular}


TABLE 8: Role of Education and Nonfarm Employment

\begin{tabular}{|l|c|c|}
\hline & $\begin{array}{c}\text { Firewood Collection } \\
\text { bharis per household } \\
\text { (uncorrected s.e.) }\end{array}$ & $\begin{array}{c}\text { Nonfarm Employment } \\
\text { fraction of household working hours } \\
\text { (uncorrected s.e.) }\end{array}$ \\
\hline Consumption & $\begin{array}{c}37.87 \\
(68.68)\end{array}$ & \\
\hline Consumption & 9.60 & \\
Square & $(748.28)$ & \\
\hline Collection Time & -0.05 & \\
\hline Collection Time & $(2.49)$ & -4.14 \\
Square & 0.02 & $(3.81)$ \\
\hline Nonfarm Empl* & $(0.29)$ & $47.13^{* * *}$ \\
Collection Time & $-0.003^{*}$ & $(15.37)$ \\
\hline Value of Land & $(0.001)$ & $-2.01^{* * *}$ \\
Owned & & $(0.43)$ \\
\hline Nonfarm Business Assets & & $1.59^{* * *}$ \\
& & $(0.39)$ \\
\hline Number of Cows & & \\
Owned & & \\
\hline Years Schooling & & \\
of Head & & \\
\hline Continued Next Page & & \\
\hline
\end{tabular}


TABLE 8 continued

\begin{tabular}{|c|c|c|}
\hline Household Size & $\begin{array}{c}1.02^{* * *} \\
(0.42)\end{array}$ & $\begin{array}{c}0.18 \\
(1.49)\end{array}$ \\
\hline $\begin{array}{l}\text { Household Size } \\
\text { Square }\end{array}$ & $\begin{array}{l}-0.04 \\
(0.02)\end{array}$ & $\begin{array}{c}0.08 \\
(0.11)\end{array}$ \\
\hline Fraction Children & $\begin{array}{l}-1.87 \\
(1.35)\end{array}$ & $\begin{array}{c}17.28 \\
(16.79)\end{array}$ \\
\hline $\begin{array}{l}\text { Fraction Prime-Age } \\
\text { Males }\end{array}$ & $\begin{array}{l}-1.11 \\
(1.34)\end{array}$ & $\begin{array}{c}14.27 \\
(16.93)\end{array}$ \\
\hline $\begin{array}{l}\text { Fraction Prime-Age } \\
\text { Females }\end{array}$ & $\begin{array}{c}0.12 \\
(1.41)\end{array}$ & $\begin{array}{c}.03 \\
(16.89)\end{array}$ \\
\hline Fraction Old Men & $\begin{array}{c}1.24 \\
(2.23)\end{array}$ & $\begin{array}{l}-15.73 \\
(21.76) \\
\end{array}$ \\
\hline Female Head & $\begin{array}{c}0.03 \\
(0.38)\end{array}$ & $\begin{array}{c}-17.17^{* * *} \\
(5.12)\end{array}$ \\
\hline Time to Market & $\begin{array}{c}0.00 \\
(0.01)\end{array}$ & $\begin{array}{l}0.004 \\
(0.04)\end{array}$ \\
\hline Time to Shop & $\begin{array}{l}-0.03 \\
(.03) \\
\end{array}$ & $\begin{array}{l}-0.07 \\
(0.25)\end{array}$ \\
\hline $\begin{array}{l}\text { Literacy of Father } \\
\text { of Head (dummy) }\end{array}$ & & $\begin{array}{c}1.02 \\
(2.82)\end{array}$ \\
\hline $\begin{array}{l}\text { Father Self-employed } \\
\text { Non-agric (dummy) }\end{array}$ & & $\begin{array}{c}17.46^{* * *} \\
(4.85)\end{array}$ \\
\hline $\begin{array}{l}\text { Father Wage Labor } \\
\text { Agri (dummy) }\end{array}$ & & $\begin{array}{l}-3.26 \\
(3.26)\end{array}$ \\
\hline $\begin{array}{l}\text { Father Wage Labor } \\
\text { Non-agri (dummy) }\end{array}$ & & $\begin{array}{c}0.89 \\
(4.48)\end{array}$ \\
\hline Age of Head & & $\begin{array}{l}-0.09 \\
(.08) \\
\end{array}$ \\
\hline $\begin{array}{l}\text { Migrant for } \\
\text { non-economic reasons (dummy) }\end{array}$ & & $\begin{array}{c}3.72 \\
(4.42)\end{array}$ \\
\hline $\begin{array}{l}\text { Upper caste } \\
\text { (dummy) }\end{array}$ & & $\begin{array}{l}-2.28 \\
(3.34)\end{array}$ \\
\hline
\end{tabular}


TABLE 9: Household (Panel Latent) Firewood Regressions in Terai and non-Terai

\begin{tabular}{|c|c|c|}
\hline & Terai & non-Terai \\
\hline Variable & $\begin{array}{c}\text { Estimate } \\
\text { (uncorr. std. err.) }\end{array}$ & $\begin{array}{c}\text { Estimate } \\
\text { (uncorr. std. err.) }\end{array}$ \\
\hline Consumption & $\begin{array}{c}275.03 \\
(209.88)\end{array}$ & $\begin{array}{c}63.12 \\
(87.68)\end{array}$ \\
\hline $\begin{array}{l}\text { Consumption } \\
\text { Square }\end{array}$ & $\begin{array}{l}-2506.10 \\
(2291.80)\end{array}$ & $\begin{array}{l}-115.57 \\
(801.24)\end{array}$ \\
\hline Collection Time & $\begin{array}{l}-0.81 \\
(0.61) \\
\end{array}$ & $\begin{array}{l}-0.02 \\
(0.35)\end{array}$ \\
\hline $\begin{array}{l}\text { Collection Time } \\
\text { Square }\end{array}$ & $\begin{array}{c}0.09 \\
(0.06)\end{array}$ & $\begin{array}{l}0.004 \\
(0.03)\end{array}$ \\
\hline $\begin{array}{l}\text { Land Owned* } \\
\text { Collection Time }\end{array}$ & $\begin{array}{c}-0.54^{* *} \\
(0.16)\end{array}$ & $\begin{array}{l}-0.11 \\
(0.21)\end{array}$ \\
\hline $\begin{array}{l}\text { Nonfarm Business Assets* } \\
\text { Collection Time }\end{array}$ & $\begin{array}{l}-4.77 \\
(5.33)\end{array}$ & $\begin{array}{c}-0.31^{* *} \\
(0.15)\end{array}$ \\
\hline $\begin{array}{l}\text { Cows Owned* } \\
\text { Collection Time }\end{array}$ & $\begin{array}{l}-0.01 \\
(0.02)\end{array}$ & $\begin{array}{c}0.01 \\
(0.01)\end{array}$ \\
\hline $\begin{array}{l}\text { Years Schooling of Head* } \\
\text { Collection Time }\end{array}$ & $\begin{array}{l}-0.04^{*} \\
(0.02)\end{array}$ & $\begin{array}{l}-0.03^{*} \\
(0.02)\end{array}$ \\
\hline Household Size & $\begin{array}{c}0.04 \\
(0.01)\end{array}$ & $\begin{array}{l}1.15^{* *} \\
(0.44)\end{array}$ \\
\hline $\begin{array}{l}\text { Household Size } \\
\text { Square }\end{array}$ & $\begin{array}{l}-0.03 \\
(0.07)\end{array}$ & $\begin{array}{l}-0.05^{*} \\
(0.03)\end{array}$ \\
\hline Fraction Children & $\begin{array}{l}-3.97 \\
(3.74)\end{array}$ & $\begin{array}{l}-0.40 \\
(4.03)\end{array}$ \\
\hline $\begin{array}{l}\text { Fraction Prime-Age } \\
\text { Males }\end{array}$ & $\begin{array}{l}-2.88 \\
(3.98)\end{array}$ & $\begin{array}{c}0.39 \\
(3.71)\end{array}$ \\
\hline $\begin{array}{l}\text { Fraction Prime-Age } \\
\text { Females }\end{array}$ & $\begin{array}{c}1.32 \\
(4.24)\end{array}$ & $\begin{array}{c}0.85 \\
(3.18)\end{array}$ \\
\hline Fraction Old Men & $\begin{array}{l}-3.70 \\
(5.46) \\
\end{array}$ & $\begin{array}{c}1.04 \\
(3.34) \\
\end{array}$ \\
\hline Female Head & $\begin{array}{c}-2.30^{* *} \\
(0.99)\end{array}$ & $\begin{array}{c}0.34 \\
(0.41)\end{array}$ \\
\hline Time to Market & $\begin{array}{l}0.67^{*} \\
(0.34)\end{array}$ & $\begin{array}{c}0.001 \\
(0.009)\end{array}$ \\
\hline Time to Shop & $\begin{array}{c}-1.27^{* *} \\
(0.54)\end{array}$ & $\begin{array}{l}-0.02 \\
(0.02)\end{array}$ \\
\hline Number of observations & 343 & 1084 \\
\hline
\end{tabular}


TABLE 10: Collection Patterns across Different Household Members for different Per Capita Consumption Quartiles

\begin{tabular}{|l|c|c|c|c|}
\hline $\begin{array}{l}\text { Mean ratio of collectors } \\
\text { to households } \\
\text { (of following category) }\end{array}$ & $\begin{array}{c}\text { Bottom } \\
\text { Quartile }\end{array}$ & $\begin{array}{c}\text { Second } \\
\text { Quartile }\end{array}$ & $\begin{array}{c}\text { Third } \\
\text { Quartile }\end{array}$ & $\begin{array}{c}\text { Top } \\
\text { Quartile }\end{array}$ \\
\hline Household head & 0.63 & 0.59 & 0.58 & 0.55 \\
\hline Spouse & 0.55 & 0.60 & 0.65 & 0.63 \\
\hline Children & 0.70 & 0.66 & 0.63 & 0.59 \\
\hline Grandchildren & 0.03 & 0.02 & 0.03 & 0.05 \\
\hline Others & 0.38 & 0.36 & 0.31 & 0.34 \\
\hline
\end{tabular}

TABLE 11:Collection Patterns across Different Household Members by Household Size and Consumption Quartiles

\begin{tabular}{|l|c|c|c|c|}
\hline $\begin{array}{l}\text { Mean ratio of collectors } \\
\text { to households } \\
\text { (of following category) }\end{array}$ & $\begin{array}{c}\text { Bottom } \\
\text { Quartile }\end{array}$ & $\begin{array}{c}\text { Second } \\
\text { Quartile }\end{array}$ & $\begin{array}{c}\text { Third } \\
\text { Quartile }\end{array}$ & $\begin{array}{c}\text { Top } \\
\text { Quartile }\end{array}$ \\
\hline \hline
\end{tabular}

Effective Household Size not exceeding 3

\begin{tabular}{|l|l|l|l|l|}
\hline Household head & 0.75 & 0.61 & 0.68 & 0.75 \\
\hline Spouse & 0.39 & 0.58 & 0.62 & 0.78 \\
\hline Children & 0.17 & 0.21 & 0.36 & 0.34 \\
\hline Grandchildren & 0.01 & 0.00 & 0.08 & 0.03 \\
\hline Others & 0.13 & 0.19 & 0.14 & 0.19 \\
\hline \hline
\end{tabular}

Effective Household Size between 3 and 5

\begin{tabular}{|l|l|l|l|l|}
\hline \hline Household head & 0.72 & 0.65 & 0.61 & 0.53 \\
\hline Spouse & 0.64 & 0.65 & 0.73 & 0.64 \\
\hline Children & 0.44 & 0.61 & 0.59 & 0.67 \\
\hline Grandchildren & 0.01 & 0.02 & 0.03 & 0.04 \\
\hline Others & 0.20 & 0.19 & 0.28 & 0.30 \\
\hline \hline
\end{tabular}

Effective Household Size between 5 and 7

\begin{tabular}{|l|l|l|l|l|}
\hline \hline Household head & 0.66 & 0.45 & 0.50 & 0.39 \\
\hline Spouse & 0.47 & 0.56 & 0.69 & 0.63 \\
\hline Children & 0.95 & 1.26 & 1.02 & 1.11 \\
\hline Grandchildren & 0.05 & 0.07 & 0.02 & 0.09 \\
\hline Others & 0.50 & 0.46 & 0.50 & 0.59 \\
\hline \hline
\end{tabular}

Effective Household Size between 7 and 9

\begin{tabular}{|l|l|l|l|l|}
\hline \hline Household head & 0.67 & 0.59 & 0.34 & 0.30 \\
\hline Spouse & 0.67 & 0.53 & 0.41 & 0.54 \\
\hline Children & 0.33 & 0.88 & 1.28 & 1.21 \\
\hline Grandchildren & 0.00 & 0.12 & 0.03 & 0.05 \\
\hline Others & 0.67 & 0.88 & 1.10 & 1.00 \\
\hline \hline
\end{tabular}


TABLE 12: Village Effect Determinants:

Random Effects Tobit

\begin{tabular}{|c|c|c|c|c|c|}
\hline Variable & $\begin{array}{c}\text { Estimate } \\
\text { (bootstr. s.e.) }\end{array}$ & $\begin{array}{c}\text { Elasticity at } \\
\text { 30th percentile }\end{array}$ & $\begin{array}{c}\text { Elasticity at } \\
\text { Median }\end{array}$ & $\begin{array}{c}\text { Elasticity at } \\
\text { 75th percentile }\end{array}$ & $\begin{array}{c}\text { Effect of one } \\
\text { one S.D. increase } \\
(95 \% \mathrm{CI}=+/-)\end{array}$ \\
\hline $\begin{array}{l}\text { Mean Consumption } \\
\text { (I) }\end{array}$ & $\begin{array}{c}175.91^{* *} \\
(84.27)\end{array}$ & 5.05 & 1.27 & 0.80 & $\begin{array}{c}2.51 \\
(2.36)\end{array}$ \\
\hline $\begin{array}{l}\text { Mean Collection Time } \\
\text { (I) }\end{array}$ & $\begin{array}{l}-0.43 \\
(0.34) \\
\end{array}$ & -3.13 & -0.78 & -0.50 & $\begin{array}{l}-1.67 \\
(1.53)\end{array}$ \\
\hline Gini Consumption & $\begin{array}{l}-3.77 \\
(3.74)\end{array}$ & -0.96 & -0.22 & -0.13 & $\begin{array}{l}-0.34 \\
(0.67)\end{array}$ \\
\hline Gini Landownership & $\begin{array}{c}0.23 \\
(2.78)\end{array}$ & 0.13 & 0.03 & 0.02 & $\begin{array}{c}0.03 \\
(0.78)\end{array}$ \\
\hline Average Poverty Gap & $\begin{array}{c}5.48 \\
(4.83)\end{array}$ & 0.21 & 0.10 & 0.11 & $\begin{array}{c}0.63 \\
(1.09)\end{array}$ \\
\hline Std. Dev. Collection Time & $\begin{array}{c}0.73 \\
(0.56)\end{array}$ & 0.87 & 0.25 & 0.17 & $\begin{array}{c}0.89 \\
(1.35) \\
\end{array}$ \\
\hline Ethnic Fragmentation & $\begin{array}{l}3.48^{* *} \\
(1.75)\end{array}$ & 0.97 & 0.28 & 0.19 & $\begin{array}{c}0.78 \\
(0.77) \\
\end{array}$ \\
\hline $\begin{array}{l}\text { Fraction in Forest User } \\
\text { Group }\end{array}$ & $\begin{array}{l}-0.22 \\
(2.14)\end{array}$ & 0.00 & 0.00 & 0.00 & $\begin{array}{l}-0.04 \\
(0.80)\end{array}$ \\
\hline Population & $\begin{array}{l}-0.19 \\
(1.39)\end{array}$ & -0.16 & -0.05 & -0.04 & $\begin{array}{l}-0.39 \\
(1.95)\end{array}$ \\
\hline Population Square & $\begin{array}{c}0.075 \\
(0.276)\end{array}$ & & & & \\
\hline Mean Household Size & $\begin{array}{c}-1.36^{* *} \\
(0.59)\end{array}$ & -5.34 & -1.16 & -0.65 & $\begin{array}{l}-0.99 \\
(0.84)\end{array}$ \\
\hline $\begin{array}{l}\text { Fraction Female Headed } \\
\text { Households }\end{array}$ & $\begin{array}{c}-4.76 \\
(4.023) \\
\end{array}$ & -0.37 & -0.08 & -0.10 & $\begin{array}{l}-0.60 \\
(0.99)\end{array}$ \\
\hline Mean Fraction Children & $\begin{array}{c}20.37 \\
(30.47) \\
\end{array}$ & 4.94 & 1.11 & 0.65 & $\begin{array}{c}1.34 \\
(3.94)\end{array}$ \\
\hline $\begin{array}{l}\text { Mean Fraction Prime-Age } \\
\text { Males }\end{array}$ & $\begin{array}{c}16.17 \\
(29.59) \\
\end{array}$ & 5.01 & 1.09 & 0.61 & $\begin{array}{c}0.85 \\
(3.06) \\
\end{array}$ \\
\hline $\begin{array}{l}\text { Mean Fraction Prime-Age } \\
\text { Females }\end{array}$ & $\begin{array}{c}20.58 \\
(28.40)\end{array}$ & 6.55 & 1.43 & 0.78 & $\begin{array}{c}0.96 \\
(2.61)\end{array}$ \\
\hline $\begin{array}{l}\text { Mean Fraction Old } \\
\text { Females }\end{array}$ & $\begin{array}{c}16.32 \\
(51.18)\end{array}$ & 0.20 & 0.05 & 0.05 & $\begin{array}{c}0.23 \\
(1.40)\end{array}$ \\
\hline $\begin{array}{l}\text { Mean of Land Owned* } \\
\text { Collection Time }\end{array}$ & $\begin{array}{l}-0.71 \\
(0.61)\end{array}$ & -0.14 & -0.05 & -0.05 & $\begin{array}{l}-1.48 \\
(2.53)\end{array}$ \\
\hline $\begin{array}{l}\text { Mean of Nonfarm Assets* } \\
\text { Colection Time }\end{array}$ & $\begin{array}{c}-3.62 \\
(10.94) \\
\end{array}$ & -0.00 & -0.00 & -0.00 & $\begin{array}{l}-0.42 \\
(2.48)\end{array}$ \\
\hline $\begin{array}{l}\text { Mean of Cows Owned* } \\
\text { Collection Time }\end{array}$ & $\begin{array}{c}0.04 \\
(0.04) \\
\end{array}$ & 0.00 & 0.00 & 0.00 & $\begin{array}{c}0.00 \\
(0.00) \\
\end{array}$ \\
\hline $\begin{array}{l}\text { Mean of Head Schooling* } \\
\text { Collection Time }\end{array}$ & $\begin{array}{l}-0.17^{*} \\
(0.09)\end{array}$ & -0.87 & -0.29 & -0.24 & $\begin{array}{l}-1.23 \\
(1.25)\end{array}$ \\
\hline \multicolumn{6}{|c|}{ TABLE 9 continued next page } \\
\hline
\end{tabular}


TABLE 12 continued

\begin{tabular}{|c|c|c|c|c|c|}
\hline Variable & $\begin{array}{c}\text { Estimate } \\
\text { (bootstr. s.e.) }\end{array}$ & $\begin{array}{l}\text { Elasticity at } \\
\text { 30th percentile }\end{array}$ & $\begin{array}{c}\text { Elasticity at } \\
\text { Median }\end{array}$ & $\begin{array}{l}\text { Elasticity at } \\
\text { 75th percentile }\end{array}$ & $\begin{array}{c}\text { Effect of one } \\
\text { one S.D. increase } \\
(1 / 295 \% \text { CI width })\end{array}$ \\
\hline Time to Dirt Road & $\begin{array}{l}-0.14^{*} \\
(0.09)\end{array}$ & -0.04 & -0.04 & -0.09 & $\begin{array}{l}-1.79 \\
(2.16) \\
\end{array}$ \\
\hline Time to Market Center & $\begin{array}{c}0.13 \\
(0.12)\end{array}$ & 0.18 & 0.05 & 0.05 & $\begin{array}{c}0.84 \\
(1.45)\end{array}$ \\
\hline Time to Paved Road & $\begin{array}{c}0.08 \\
(0.07)\end{array}$ & 0.14 & 0.05 & 0.10 & $\begin{array}{c}1.22 \\
(1.92)\end{array}$ \\
\hline Elevation & $\begin{array}{c}2.49 \\
(1.55)\end{array}$ & 0.00 & 0.00 & 0.00 & $\begin{array}{c}0.00 \\
(0.00)\end{array}$ \\
\hline Elevation Squared & $\begin{array}{l}-0.38 \\
(0.38)\end{array}$ & & & & \\
\hline Natural Disaster Dummy & $\begin{array}{l}-1.27 \\
(0.90) \\
\end{array}$ & 0.00 & -0.25 & -0.13 & $\begin{array}{l}-0.63 \\
(0.88) \\
\end{array}$ \\
\hline $\begin{array}{l}\text { No. of observations }=1350 \\
\text { Wald chi-sq }(30)=154.70 \\
446 \text { left-censored observati } \\
\text { constant term and region } \\
\text { (I) denotes instrumented; } \\
\text { Simulations computed at }\end{array}$ & $\begin{array}{l}130 \text { villages. } 55 \\
\text { p-value for chi-s } \\
\text { ns, } 904 \text { uncenso } \\
\text { ammies includec } \\
\text { *: significant at } \\
\text { edian values for }\end{array}$ & $\begin{array}{l}\text { runs for bootstr } \\
\text { test for joint sig } \\
\text { ebservations } \\
\text { in regression, no } \\
\% \text {; *: significant } \\
\text { ariables entering }\end{array}$ & $\begin{array}{l}\text { ificance }=0.00 \\
\text { reported here } \\
\text { t } 10 \% \text {. } \\
\text { conlinearly }\end{array}$ & & \\
\hline
\end{tabular}


TABLE 13: Censored Regressions of Collections on Consumption

\begin{tabular}{|c|c|c|c|c|}
\hline & \multicolumn{3}{|c|}{ Intravillage } & \multirow{2}{*}{$\begin{array}{c}\text { Intervillage } \\
\text { Cons. Exog. }\end{array}$} \\
\hline & Cons. Instr. & Cons. Exog. & Cons. Exog. & \\
\hline Consumption & $\begin{array}{c}145.42^{* *} \\
(63.56)\end{array}$ & $\begin{array}{c}97.78^{* * * *} \\
(17.29)\end{array}$ & $\begin{array}{c}200.47^{* * *} \\
(44.56)\end{array}$ & $\begin{array}{l}-79.53 \\
(54.12)\end{array}$ \\
\hline Consumption Sq. & $\begin{array}{l}-1015.85 \\
(771.16)\end{array}$ & $\begin{array}{c}-350.19^{* * *} \\
(80.33)\end{array}$ & $\begin{array}{c}-2397.02^{* *} \\
(934.14)\end{array}$ & $\begin{array}{l}743.57^{* *} \\
(338.62)\end{array}$ \\
\hline Consumption Cube & & & $\begin{array}{c}12930.36^{* *} \\
(6272.26)\end{array}$ & \\
\hline Consumption 4 th power & & & $\begin{array}{c}-23646.62^{* *} \\
(11962.93)\end{array}$ & \\
\hline Consumption*Coll. Time & $\begin{array}{l}0.86 \\
(.60)\end{array}$ & $\begin{array}{c}1.38 \\
(2.19)\end{array}$ & $\begin{array}{c}1.57 \\
(2.21)\end{array}$ & $\begin{array}{l}-7.28 \\
(5.21) \\
\end{array}$ \\
\hline Number of Households & 1321 & 1559 & 1559 & \\
\hline \multicolumn{5}{|c|}{${ }^{*}$ : significant at $10 \%,{ }^{* *}$ : significant at $5 \%,{ }^{* * *}$ : significant at $1 \%$} \\
\hline \multicolumn{5}{|c|}{ Standard errors in parentheses } \\
\hline
\end{tabular}


TABLE 14: Unconditional APEH Censored Intravillage Regression

\begin{tabular}{|c|c|c|c|c|}
\hline & Whole Sample & Whole Sample & Whole Sample & Non-terai Sample \\
\hline \multirow[t]{2}{*}{ Value of Land } & $4.68^{* *}$ & 0.29 & $4.47^{* *}$ & 3.02 \\
\hline & $(2.09)$ & $(.76)$ & $(2.02)$ & $(1.37)$ \\
\hline \multirow[t]{2}{*}{ Value of Land Sq. } & $-1.17^{*}$ & & $-1.20^{* *}$ & $-.91^{*}$ \\
\hline & $(.47)$ & & $(.49)$ & $(.53)$ \\
\hline \multirow[t]{2}{*}{ Nonfarm Bus Assets } & -16.19 & $-14.83^{* *}$ & $-70.58 * * *$ & 2.65 \\
\hline & $(23.51)$ & $(6.41)$ & $(17.19)$ & $(16.85)$ \\
\hline \multirow[t]{2}{*}{ Nonfarm Assets Sq } & 0.07 & & -1.66 & -2.63 \\
\hline & $(4.51)$ & & $(4.02)$ & $(3.40)$ \\
\hline Nonfarm & & & $64.57^{* * *}$ & \\
\hline Assets*Nonterai Dummy & & & $(20.63)$ & \\
\hline \multirow[t]{2}{*}{ Cows Owned } & 0.22 & $0.18^{*}$ & 0.24 & $0.34^{*}$ \\
\hline & $(0.17)$ & $(.09)$ & $(.17)$ & $(.19)$ \\
\hline \multirow[t]{2}{*}{ Cows Owned Sq. } & -.005 & & -.005 & -.007 \\
\hline & $(.009)$ & & $(.009)$ & $(.010)$ \\
\hline \multirow[t]{2}{*}{ Education Head } & $0.27^{*}$ & -0.02 & $0.27^{*}$ & $0.28^{*}$ \\
\hline & $(.15)$ & $(.08)$ & $(.15)$ & $(.16)$ \\
\hline \multirow[t]{2}{*}{ Education Head Sq. } & $-0.03^{* * *}$ & & $-0.03^{* *}$ & $-0.03^{* *}$ \\
\hline & $(.01)$ & & $(.01)$ & $(.01)$ \\
\hline Pred. Coll. & $-0.58^{*}$ & -0.19 & $-0.52^{*}$ & -0.23 \\
\hline Time*Land & $(.30)$ & $(.17)$ & $(.27)$ & $(.26)$ \\
\hline Pred. Coll. & 2.11 & $1.95^{* *}$ & 1.15 & .16 \\
\hline Time*Nonfarm Assets & $(2.07)$ & $(.88)$ & $(1.76)$ & $(1.43)$ \\
\hline Pred. Coll. & -0.004 & -0.006 & -0.005 & -0.015 \\
\hline Time*Number Cows & $(.017)$ & $(.017)$ & $(.016)$ & $(.018)$ \\
\hline Pred. Coll. & -0.016 & -0.013 & -0.015 & -0.016 \\
\hline Time*Education Head & $(.017)$ & $(.019)$ & $(.017)$ & $(.019)$ \\
\hline Number of Households & 1427 & 1427 & 1427 & 1084 \\
\hline \multicolumn{5}{|c|}{${ }^{*} *$ : significant at $10 \%, * *$ : significant at $5 \%, * * *$ : significant at $1 \%$} \\
\hline \multicolumn{5}{|c|}{ Standard errors in parentheses } \\
\hline Regr & family demog & aphics, location, & llection time & square \\
\hline
\end{tabular}


TABLE 15: Simulated Change in Firewood Collection

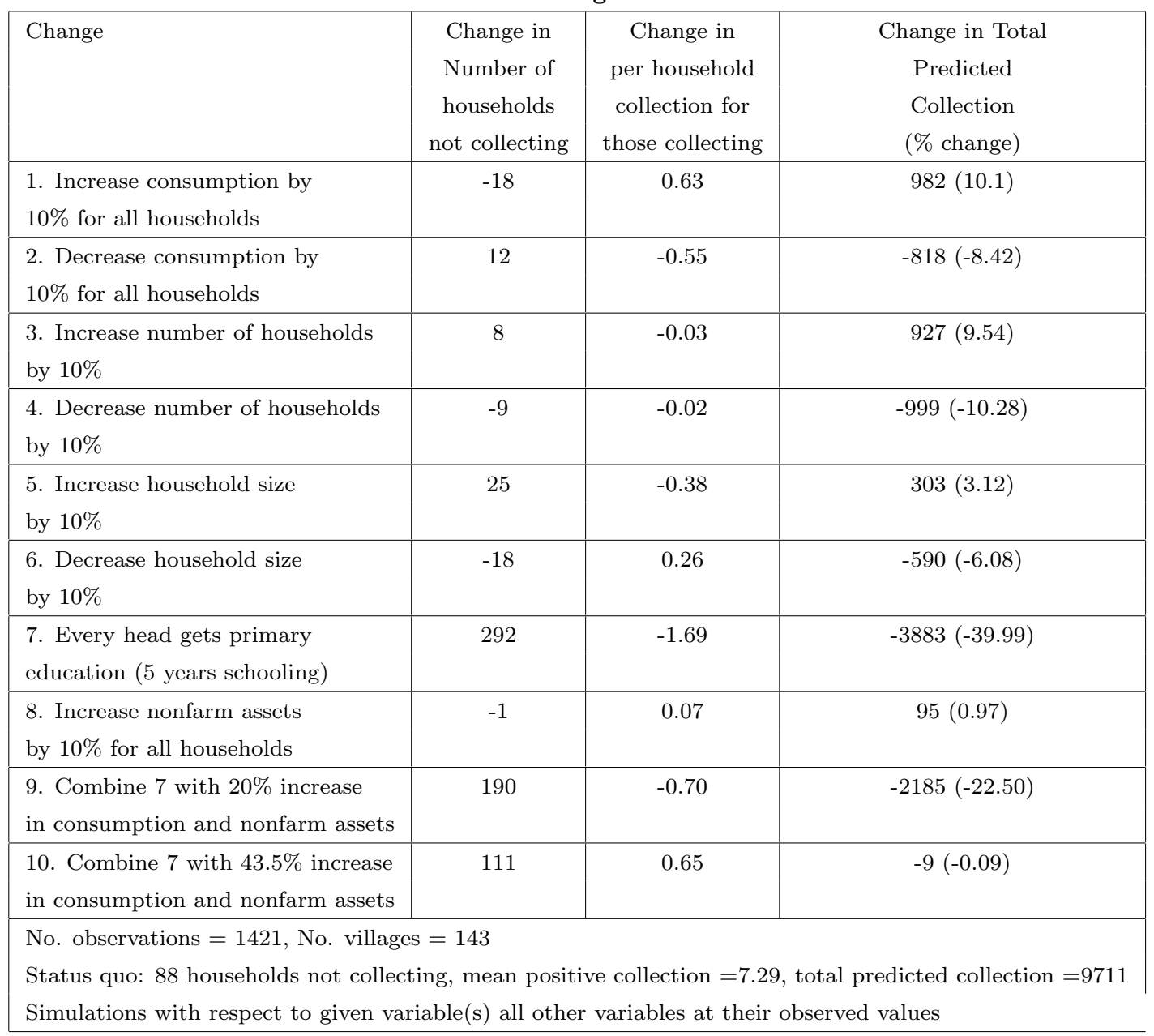




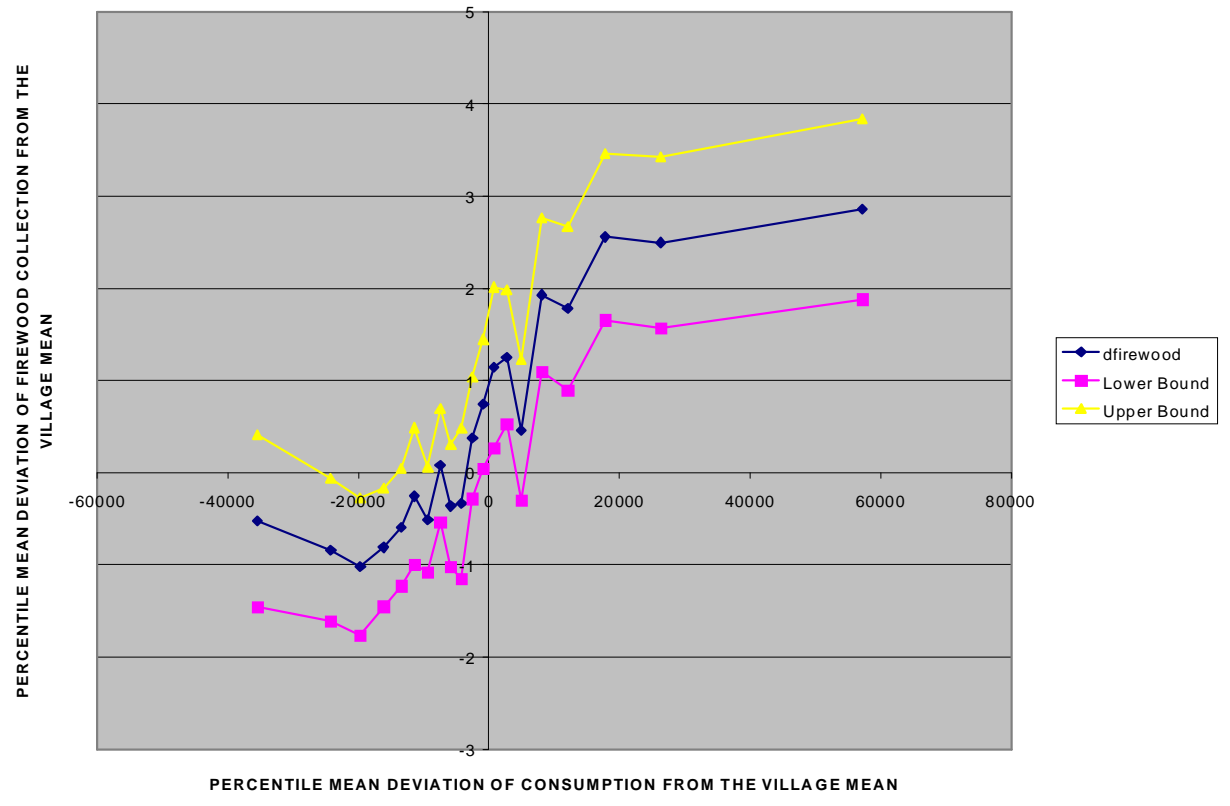

Figure 1: IntraVillage Firewood Collection-Consumption Plot, Deviations From Village MEAN 


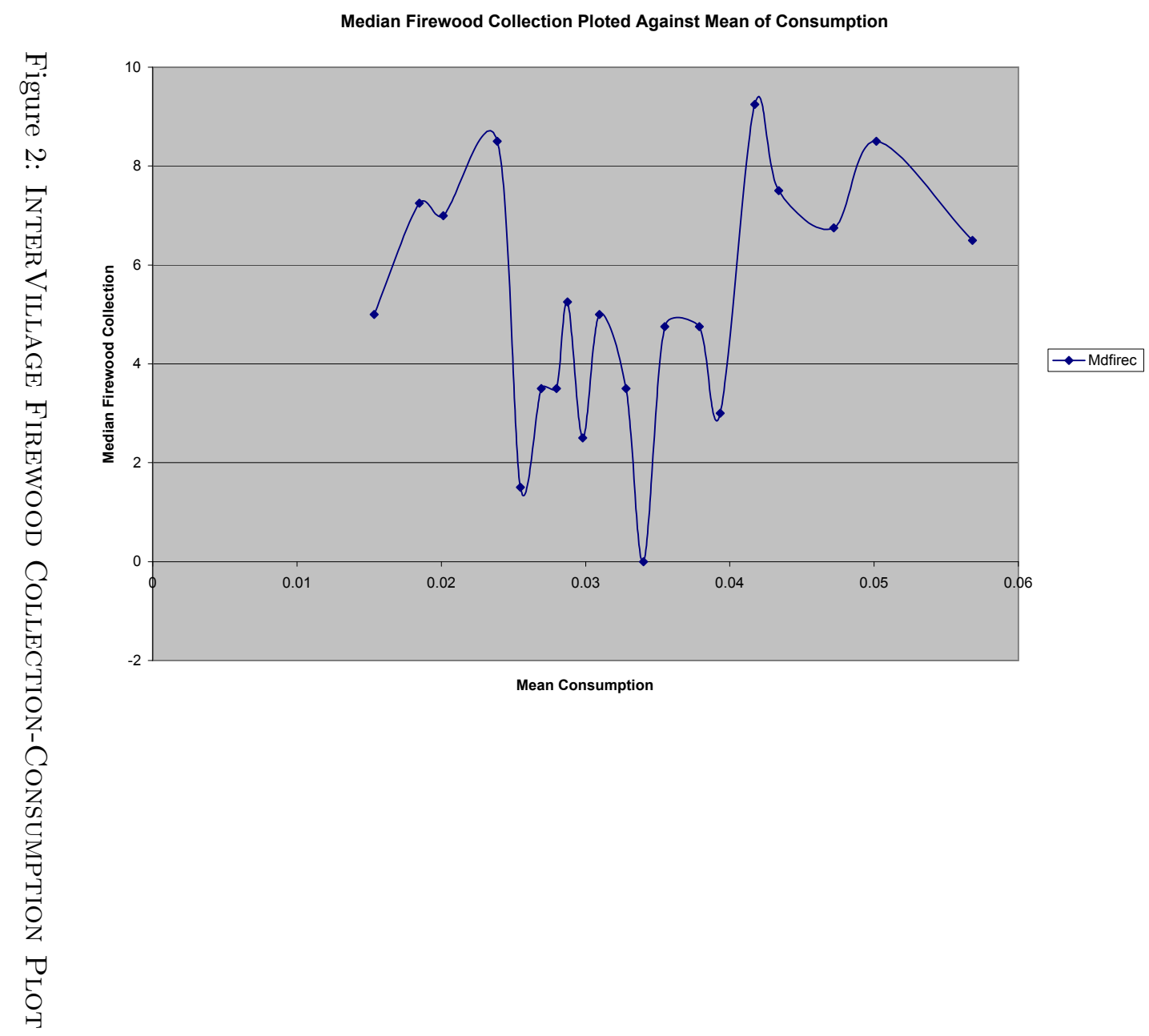




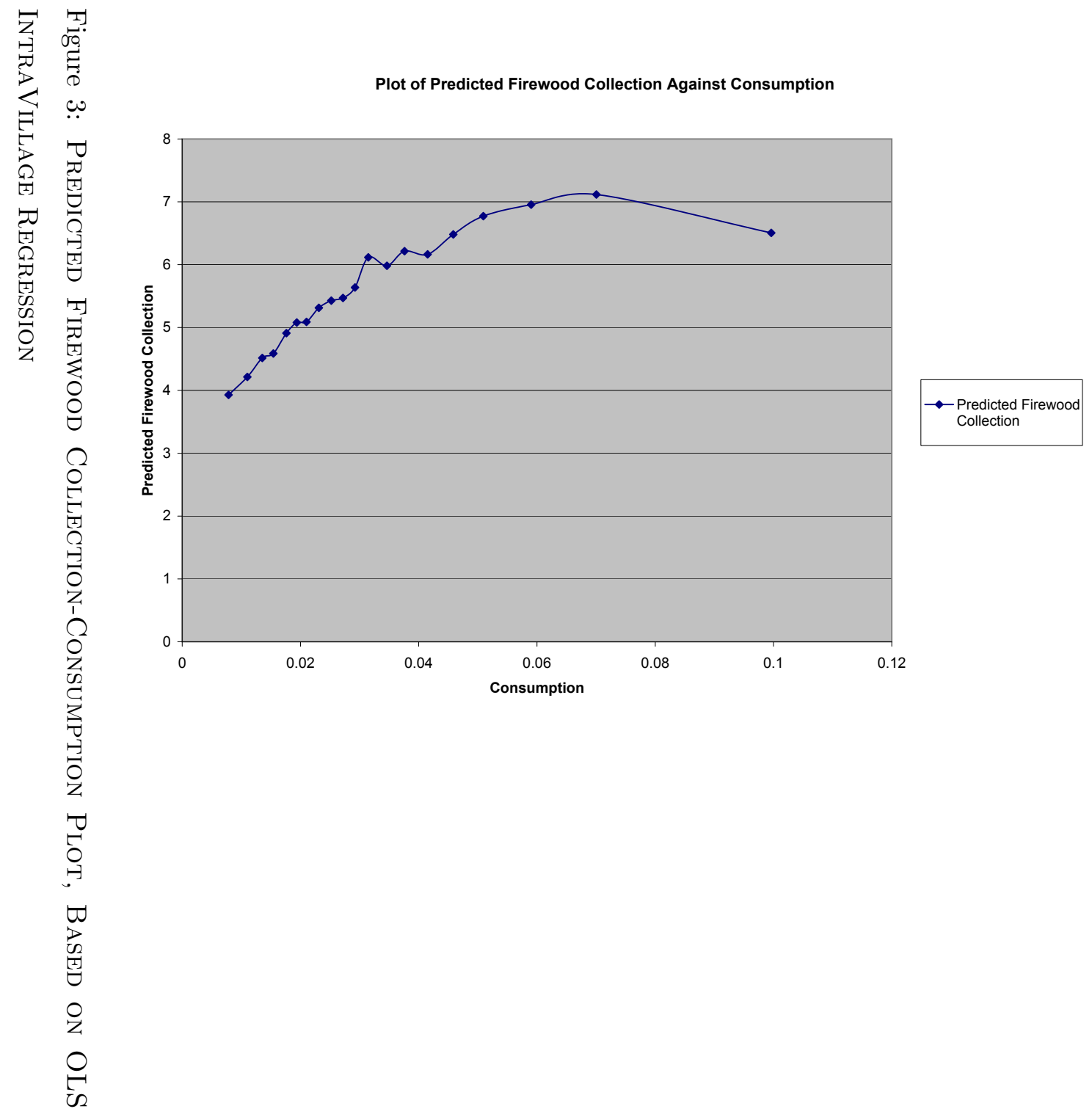




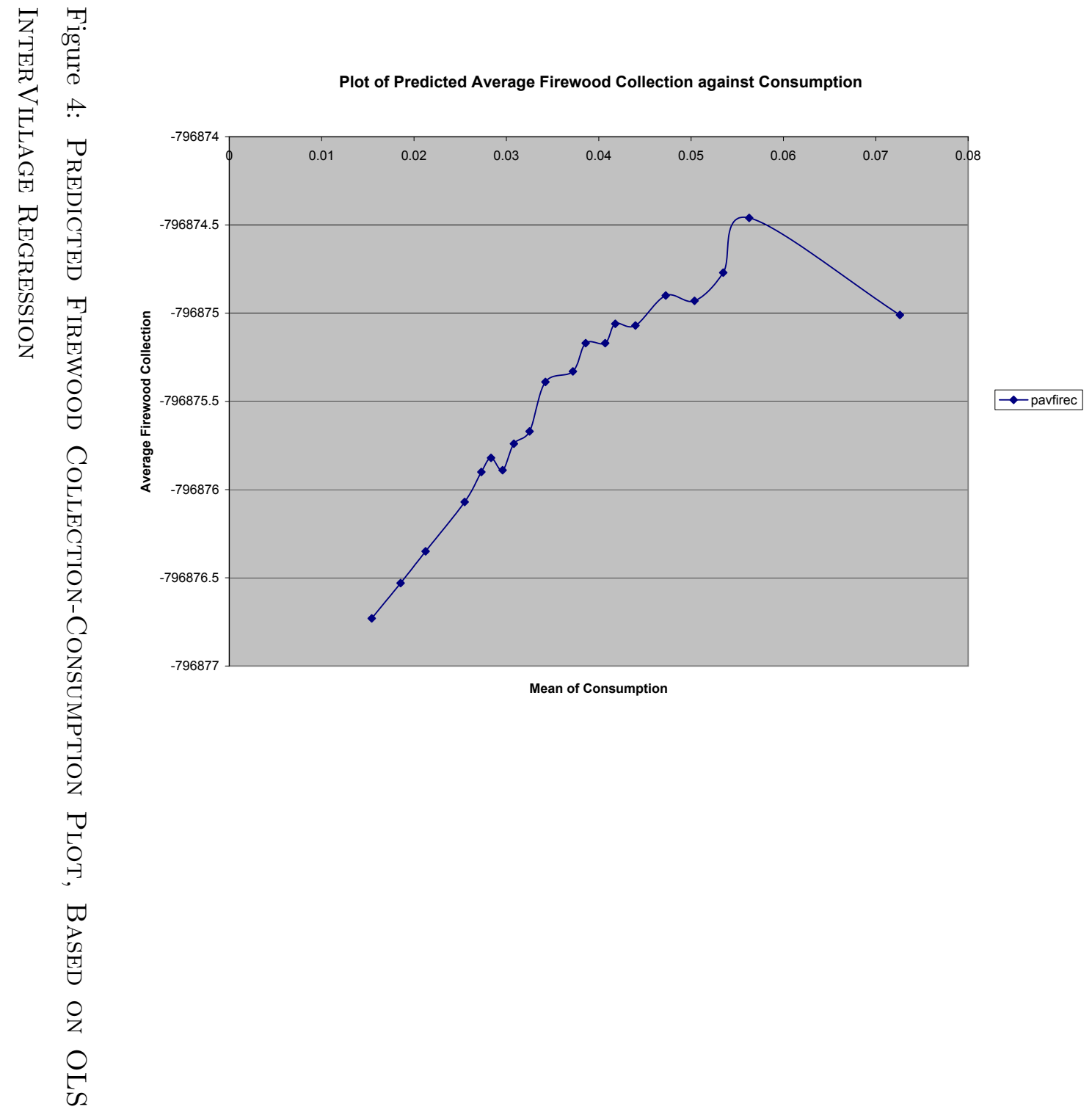




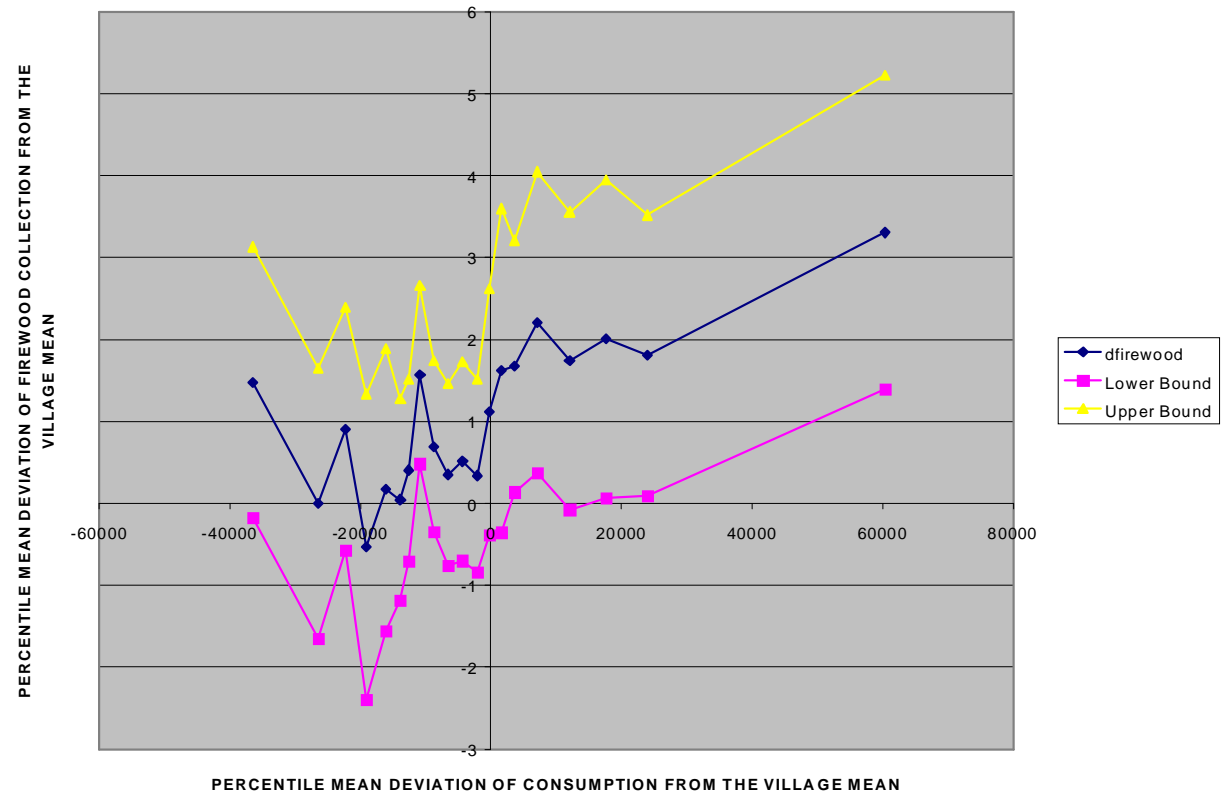

Figure 5: Collections-Consumption Relationship in Terai, Deviations from VilLAGE MEAN 


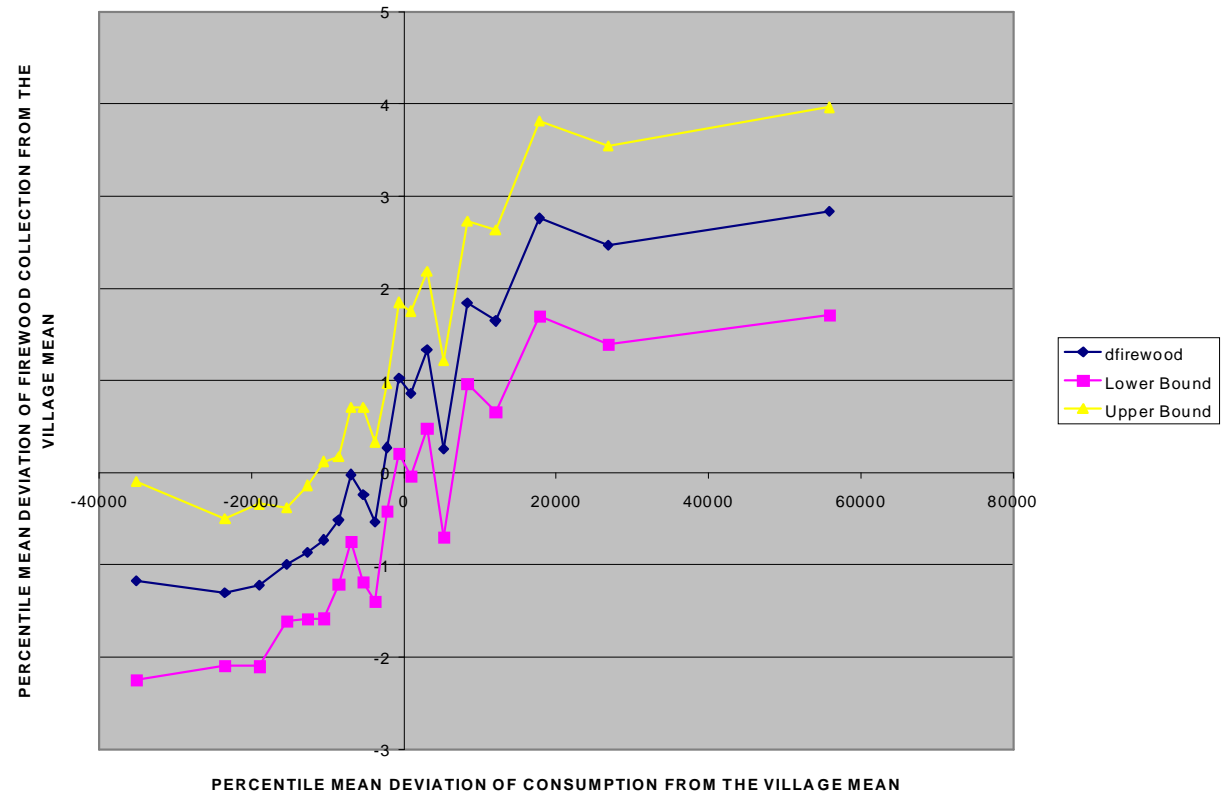

Figure 6: Collections-Consumption Relationship in non-Terai, Deviations from Village MeAN 


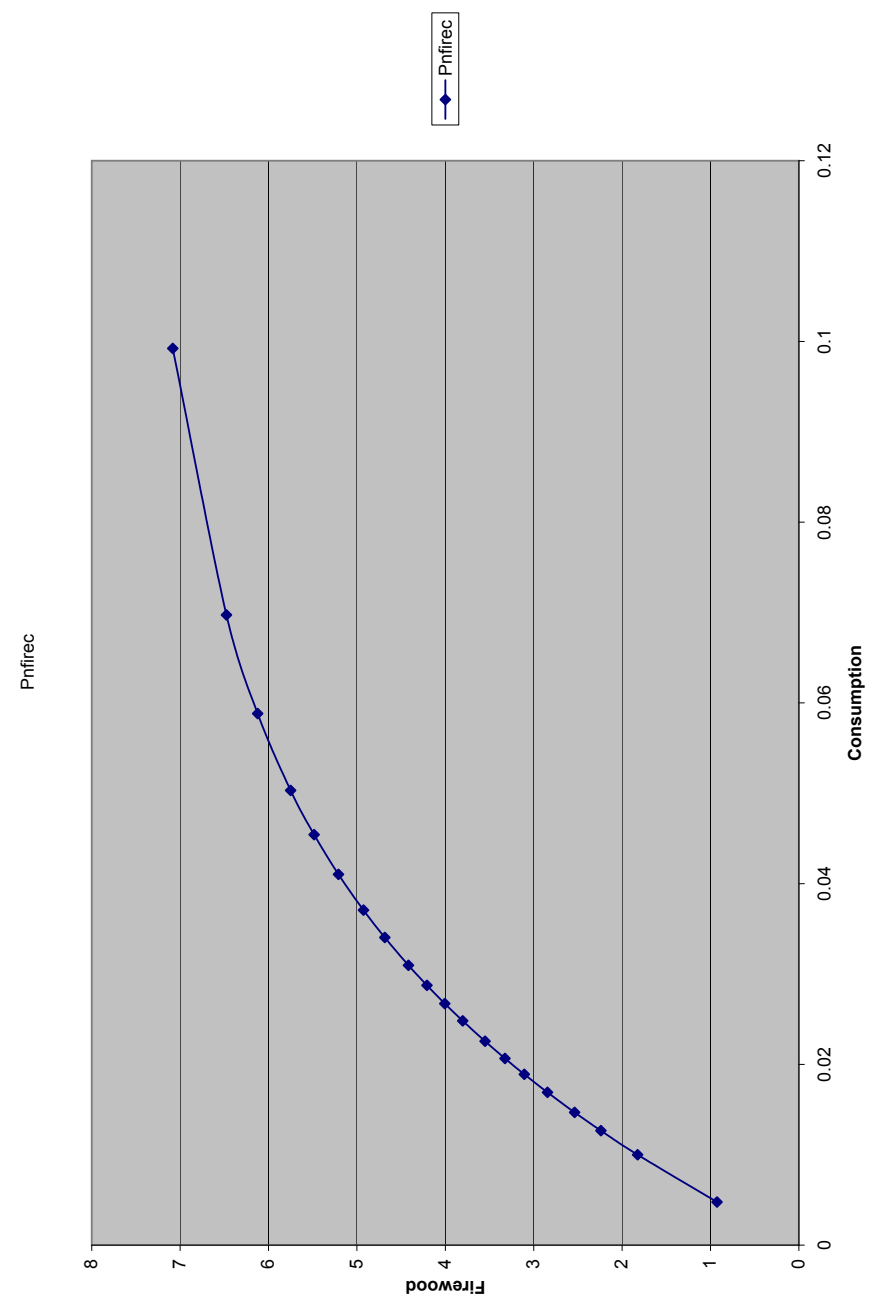

Figure 7: Estimated Unconditional Engel Curve, Based on Intravillage CenSORED REGRESSION 